\title{
Unconventional Monetary Policy, Competition and Financial Stability. Evidence from the Eurozone Banks
}

\author{
ANE BAKAIKOA PEDROSA \\ Departamento de Gestión de Empresas, \\ Universidad Pública de Navarra \\ e-mail: anebp19@gmail.com \\ JOSÉ MANUEL MANSILLA FERNÁNDEZ \\ Departamento de Gestión de Empresas e INARBE \\ Universidad Pública de Navarra \\ ESPAÑA \\ e-mail: josemanuel.mansilla@ unavarra.es
}

\begin{abstract}
This article analyses the effects of the ECB's negative interest rates (or unconventional) policy on the degree of banking competition, lending and deposit supply, and financial stability. Using a dataset comprising 191 Eurozone banks for the 2002Q1-2016Q4 period, our results suggest that negative interest rates (i) increase banks' lending and deposit supply, (ii) reduce banking competition, and (iii) weaken financial stability. This phenomenon is economically more significant for periphery country banks than for core country banks.
\end{abstract}

Keywords: Bank competition, financial stability, lending and deposit supply, negative interest rates, quantitative easing.

Política monetaria no-convencional, competencia, y estabilidad financiera. Evidencia para los bancos de la zona euro.

\section{RESUMEN}

Este trabajo analiza los efectos de la política monetaria de tipos negativos (no convencional) sobre el grado de competencia bancaria, la oferta de crédito y depósitos y la estabilidad financiera. Utilizando una base de datos que incluye 191 bancos de la zona euro para el periodo 2002Q1-2016Q4, los resultados sugieren que los tipos de interés negativos (i) incrementan la oferta de crédito y depósitos, (ii) reducen la competencia bancaria, y (iii) debilitan la estabilidad financiera. Este fenómeno es económicamente más significativo para los bancos de los países periféricos que para los bancos de los países centrales.

Palabras clave: Competencia bancaria, estabilidad financiera, expansión cuantitativa, oferta de crédito y depósitos, tipos de interés negativos.

Clasificación JEL: E52 G01 G21 G28. 


\section{INTRODUCTION}

The 2008 financial crisis presented policy makers with a challenge in the form of stagnation, high unemployment rates and deflation. In October 2008, the European Central Bank (hereafter, ECB), along with the leading central banks, responded promptly by introducing the so-called accommodative monetary policies aimed at reviving lending to the real sector. Once macroeconomic interest rates approached the zero-lower bound without achieving the desired effects of inflation and economic growth, the ECB implemented the unconventional monetary policy in the form of quantitative easing ( $\mathrm{QE}$ hereafter) and forward guidance on monetary policy rates (BdE, 2017). The unconventional monetary policy resulted in negative interest rates aimed at augmenting the cost to banks of holding reserves in the central banks encouraging them to back to their balance sheet (Molyneux et al., 2019 a,b). Below zero interest rates were supposed to increase lending and deposits by reducing funding and marginal costs for banks, thereby benefiting borrowers. However, negative interest rates also squeezed margins and profitability. Banks responded with waves of mergers to become larger size and thus achieve economies of scale. This reduced the number of competitors and the degree of competition in the Eurozone banking markets (see Figure 1). In specific terms, the first question posed by this paper is: Can it be proved that negative interest rates increased banks' supply of loans and deposits? The literature investigating the unconventional monetary policy in different economic areas remains divided as to its repercussions on the real sector (Bowman et al., 2015; Chakraborty et al., 2019; Rodnyansky and Darmouni, 2017). Figure 1 illustrates the motivation of this research.

\section{[Figure 1]}

The second question that this research endeavours to answer is whether reductions in competition might condition the transmission of the unconventional monetary policy. More accurately, the research question can be formulated as follows: Can it be proved that reductions in the number of competitors in the Eurozone banking market might drive the transmission of the unconventional monetary policy? Previous studies suggest that reductions in margins and profitability (Molyneux et al., 2019a,b) pushed banks to begin consolidation processes in order to increase their size and achieve economies of scale (Andreeva and Garcia-Posada, 2019). Interestingly, the Eurozone banking markets become more concentrated after the ECB's QE. In line with recent research demonstrating that the degree of banking competition is a determinant of financial stability (e.g., Arping, 2019), we extend our research question as 
follows: Can it be proved that the above-mentioned reduction in competition affected financial stability? We measure the degree of banking concentration as the natural logarithm of the number of banks operating in each country, and the Herfindhal-Hirschman index of credit and deposits markets.

The empirical analysis for this research is based on a high-frequency panel dataset drawn from Bankscope (Bureau van Dijk) containing 191 Eurozone banks for the 2002Q1 - 2016Q4 period. These data are completed with macroeconomic data from Thomson Reuters Datastream. As for the variables used in this study, loan and deposit supplies are measured using the loans to total assets ratio and the deposits to total assets ratio, respectively. Financial stability is analysed using the natural logarithm of the Z-score indicator as employed in the financial literature to measure the inverse probability of bank default (Laeven and Levine, 2009; Liu et al., 2013; Schaeck et al., 2012), and the non-performing loans (NPL hereafter) ratio computed as impaired loans over total loans (Chiesa and Mansilla-Fernández, 2018; Ghosh et al., 2016). Following previous studies (Carbó-Valverde et al., 2009, 2017b; Fernández de Guevara et al., 2005), we measure the degree of competition between banks using the Lerner index, which measures the bank's market power as the distance between price and marginal costs. We use panel data techniques, i.e. fixed effects and random effect estimators, to assess the impact of (negative) interest rates on lending and deposits markets. We check the validity of each estimator using the Hausman test. Heteroscedasticity and autocorrelation issues are checked through the Breusch-Pagan test and the Wooldridge test, respectively. Finally, the instrumental variables (IV) estimator is employed to check the functioning of the complete negative interest rates-bank concentration-lending and deposits supply transmission channel. This research contributes to previous literature by revealing that negative interest rates might drive market concentration in the banking sector, and thereby condition the transmission of the (unconventional) monetary policy through the supply of loans and deposits, and reduce financial stability.

The remainder of the paper is organized in five sections following this introduction. Section 2 discusses the related literature. Section 3 summarizes the latest decisions of the ECB on monetary policy. Section 4 defines the database and describes the empirical model and study variables. Section 5 provides a discussion of the results, and the article closes with a concluding section. 


\section{LITERATURE REVIEW}

This section presents a brief discussion on the theoretical interests guiding the research questions presented in this study, and an explanation of how this paper fits into the existing literature.

The first research question is whether QE by the ECB, which materialized in the form of negative interest rates, affected the supply of loans and deposits by the Eurozone banks. Until the beginning of the crisis, the standard economic literature continued to develop the idea that liquidity is ineffective once interest rates reach their lower bound (Eggertsson and Woodford, 2003; Wallace, 1981). Recent empirical evidence shows, in this respect, that negative interest rates might also work against economic growth by reducing the prices of assets held by economic agents (Del Negro et al., 2017). Interestingly, Brunnermeier and Kobby (2019) introduce the 'reversal interest rate hypothesis', which predicts the existence of an interest rate threshold at which an accommodative monetary policy 'reverses' its objectives and becomes contractionary. The reversal interest rate depends on several factors, such as the composition of banks' assets, the degree of pass-through to the loans and deposits rates, and banks' funding structure (Brunnermeier and Sannikov, 2016; Drechsler et al., 2017). Little is known, however, about the transmission channels through which unconventional monetary policies affect credit and deposit markets, and thus impact on the real economy. Recent theoretical models demonstrate that, under heterogeneous agents and market imperfection, unconventional monetary policy programmes might increase banks' reserves and thereby boost lending to the real sector (Cúrdia and Woodford, 2011). Berger et al. (2017), who analyse the effects of term auction facilities, find an increase in short- and long-term lending in several loan categories. In this regard, while fostering mortgage lending, the unconventional monetary policy (Rodnyansky and Darmouni, 2017) also crowded out other forms of credit (Chakraborty et al., 2019). Studying the Japanese market, Bowman et al. (2015) find a significant effect of bank liquidity positions on lending linked to the unconventional monetary policy. Our paper contributes to the previous literature by demonstrating that negative interest rates foster banks' supply of loans and deposits. Interestingly, the sensitivity to negative interest rates is found to be more significant in economic terms for deposits than for loans, which explains banks' preferences for 'traditional' forms of funding. To the best of our knowledge, ours is one of the 
first studies to extend this analysis to look for differences in the impact of the unconventional monetary policy between the two 'Europes' (see Chiesa and Mansilla-Fernández, 2018).

The second question that this article endeavours to answer is whether changes in the degree of banking competition might act as a barrier to the ECB's QE. Previous studies have demonstrated that negative interest rates erode banks' net interest margins by potentially reducing the value of their assets (Molyneux et al., 2019 a,b). Concurrently, lower (or even negative) interest rates reduce the cost of bank liabilities, i.e., funding costs. Unlike what would be found in a 'conventional' monetary policy environment, banks relying on deposit rates are reluctant to reduce their lending rates for fear of losing their funding base (Chaudron, 2018). Arteta et al. (2016) demonstrate that lending rates decline when interest rates become negative, particularly in countries where banking competition is relatively high. Recent research demonstrates that an unconventional monetary policy might affect banks' marginal costs, and, ultimately, the degree of competition. Negative interest rates reduce banks' funding costs-i.e., the cost of their inputs-, thus enabling banks to expand their loan supply through marginal cost reductions (Andreeva and Garcia-Posada, 2019). Banks' capitalization also plays a key role in the effects of negative interest rates on the degree of competition in banking markets. Undercapitalized banks, which usually have difficulty raising capital, might reduce their profitability if the decrease in loan rates outweighs reductions in marginal costs.1 Furthermore, if competition between banks is fierce, both loan and deposits rates will decline, thus squeezing margins. The results of our study suggest that the wave of bank mergers gathered intensity once interest rates became negative, thus concentrating the Eurozone loan and deposits markets and reducing the degree of competition. In other words, this paper contributes to the existing literature by demonstrating that an unconventional monetary policy might reduce banking competition, thus affecting both the loans and the deposits on banks' balance sheets. 2

The third question that this study attempts to answer is whether the effect of the abovementioned changes in the degree of banking competition on financial stability was due to the expansionary monetary policy. Recent economic literature has investigated the relationship

\footnotetext{
${ }^{1}$ It can be assumed that banks with lower profits can be viewed as riskier by investors (Chiesa and Mansilla-Fernández, 2018). Bank borrowers and equity investors may question the viability of the financial institution and hence demand non-diversifiable risk compensation (Aiyar et al., 2015). Banks' fund raising difficulties can make lending more costly and thus shift the marginal costs curve (Degryse and Ongena, 2008; Ongena and Popov, 2009; VanHoose, 2017).

${ }^{2}$ Whereas previous literature analysing the so-called 'direct channel' focused on the impact of negative interest rates on lending growth for banks participating in the ECB's programmes, this research builds on the theory advocating that reductions in the degree of competition impact on banks' lending and deposits supply following negative interest rates, namely the 'indirect channel' (Andreeva and Garcia-Posada, 2019).
} 
between the degree of competition and the stability of the banking sector (Allen and Gale, 2004; Coccorese, 2004, 2009; Martinez-Miera and Repullo, 2010). Our results support the socalled 'competition stability' view, which predicts that banks operating in a low competition environment raise loan prices to relatively uncompetitive levels, thus increasing borrower default risk and threatening financial stability (Boyd and De Nicolò, 2005).3 Then, competition might put downward pressure on net interest margins, thus increasing the bank's probability of default (Molyneux et al., 2019 a, b). Interestingly, the transmission channel discussed in this paper might be of interest to the regulatory authorities. If negative interest rates result in a decline of profitability, banks will reduce their earnings and capital base. Consequently, banks might relax their lending standards and issue loans to relatively credit unworthy customers, which might generate more impaired (or non-performing) loans and erode financial stability (Busch and Memmel, 2017; Claessens et al., 2018; Ghosh, 2017; Grigoli et al., 2018).4 Banks' and depositors' 'move-into-cash' behaviour could hamper the monetary policy transmission mechanism and weaken financial stability. Cash hoarding by banks would undermine the effectiveness of the unconventional monetary policy. Furthermore, the risk of deposits flight might increase liquidity risk in the banking sector, and thus threaten financial stability (Heider et al., 2019; Lopez et al., 2018). We build on the theory that changes in banking competition play a mediating role in the mechanism through which the monetary policy improves the soundness of the banking sector. Our results confirm that the "competition-stability" view can be verified for periphery country banks, which are more vulnerable to the consequences of inherited non-performing loans and the deleveraging phase of the sovereign debt crisis.

\section{RECENT ECB MONETARY POLICY DECISIONS IN A NUTSHELL}

Before the crisis, the ECB served the estimated liquidity needs of the banking system on a weekly basis via open market operations; the monetary base was exogenously determined by the central bank; and EONIA was set at a positive rate. In 2007-2008, the advanced economies

\footnotetext{
${ }^{3}$ Alternatively, the 'competition fragility' view argues that banks operating in a high-competition environment reduce their mark-ups and the franchise value of the bank. Banks will then intensify their risk-taking behaviour. The logic behind this view is that banks with relatively higher monopoly power are able to identify larger numbers of creditworthy customers, and this enables them to enhance their interest margins and while promoting banking sector stability (Coccorese, 2004, 2008; IJtsma et al., 2017; Goetz, 2018).

${ }^{4}$ The moral hazard hypothesis predicts that banks with relatively low capitalization levels are more likely to generate impaired loans by reducing the quality of their loan portfolios in a 'gamble to resurrection' (Berger and DeYoung, 1997; Bouwman and Malmendier, 2015).
} 
suffered the biggest financial crisis since the 1930s, followed by a severe post-crisis recession which questioned the adequacy of traditional tools.

The ECB announced "Long Term Repurchase Operations" (LTROs), "Main Refinancing Operations" (MRO)" and "Outright Monetary Transactions" (OMT) in September 2008, in order to support bank lending and money market activity. As part of this change, the ECB switched to fixed-rate tenders with full allotment in all liquidity-providing operations in October 2008, thus giving banks better access to liquidity. The programs were phased out in 2010 but reintroduced later. In May 2009, the ECB announced a Covered Bond Purchase Program under which they purchased $€ 60$ billion of private sector bonds. In May 2010, they introduced a Securities Market Program, and, in November 2011, launched a second covered bond purchase program, CBPP2, which was to last until October 2012, when these programs were declared terminated because the ECB was unable to convince the market that they did not incur default risk.

Although the ECB announced the QE in the Euro Area in January 2015, asset purchases began in March 2015. The announced plan was to buy at least $€ 1.1$ trillion of public sector debt and private sector assets between the start of 2015 and September 2016.

After the first year of the QE, in March 2016, the ECB lowered the interest on the main refinancing operations and on the marginal lending facility; increased monthly bond purchases (from $€ 60$ billion to $€ 80$ billion); added corporate bonds to the list of assets eligible for regular purchases; targeted new long-term loans (TLTRO II); and reiterated forward guidance on borrowing costs.

The ECB decided to reduce purchases to $€ 60$ billion in April of 2017, having declared the economy to be in a state of recovery. Later, in October of the same year, Mario Draghi announced a $€ 30$ billion monthly pace of asset purchases from January 2018 until the end of September 2018, stressing that the purpose of the reinvestments was to provide a monetary stimulus. Finally, in the last quarter of 2018, the ECB decided to phase out APP to $€ 15$ billion Euros.

\section{HYPOTHESES, DATA, AND METHODOLOGY}

\subsection{Hypotheses}


The purpose of this research is to analyse the repercussions of the ECB's QE for banks' business, banking competition and financial stability, making a distinction between banks headquartered in core versus periphery countries. Based on the literature discussed above, we propose the following testable hypotheses:

Hypothesis 1: Negative interest rates increase customer loans and deposits.

Hypothesis 2: Negative interest rates reduce banking competition.

Hypothesis 3: Negative interest rates reduce financial stability.

\subsection{Data}

Bank balance sheet data information are drawn from Bureau van Dijk's Bankscope and Orbis Bank Focus. The sample consists of quarterly data for a sample of Eurozone banks covering the 2002Q1-2016Q4 period. ${ }^{5}$ We include consolidated balance sheets and income statements of commercial banks, savings banks, and credit unions. All the banks included in the sample report financial data from January $1^{\text {st }}$ to December $31^{\text {st }}$. Finally, to avoid issues of ambiguity and double-counting of banks, we choose financial statements at the highest possible level of consolidation, usually as banking groups.

The data are expressed in thousands of Euros and are adjusted for inflation. For the sake of consistency, zero total assets, zero employee and negative balance sheet values have been filtered out. This yielded a total of 11,460 observations for 191 (individual) banks over 60 quarters.

The years covered by the sample are relevant because they include the pre-crisis period (2002Q1-2008Q4), the time span between the implementation of the fixed-rate full allotment policy and the beginning of the sovereign debt crisis (2009Q1-2014Q4), and the period in which the APP was implemented, lowering interest rates to below zero (2015Q1-2016Q4).

The macroeconomic time series data for each country were drawn from the Thomson Reuters Datastream database. The banking and macroeconomic data were then combined into a single panel.

Appendix A contains the definitions of the study variables winsorized at $1 \%$ to remove any outliers that might skew the results.

\footnotetext{
${ }^{5}$ The Eurozone countries are Germany, Austria, Belgium, Cyprus, Slovakia, Slovenia, Spain, Estonia, Finland, France, Greece, Holland, Ireland, Italy, Latvia, Lithuania, Luxembourg, Malta, and Portugal.
} 


\subsection{Measuring banking competition: The risk-adjusted Lerner index}

To measure of the degree of competition in the Eurozone banking markets, this study uses the risk-adjusted Lerner index, which measures the mark-up (that is, the price charged from customers above the marginal costs) as a percentage of prices. The Lerner index ranges from zero to one, where Lerner ${ }_{i t}=0$ indicates perfect competition, Lerner $_{i t}=1$ indicates perfect monopoly, and Lerner $_{i t}<0$ indicates the exceptional case of banks performing non-optimally. The Lerner index is calculated as follows:

$$
\text { Lerner }_{i t}=\frac{P_{i t}-M C_{i t}}{P_{i t}}
$$

where the subscripts $i$ and $t$ denote the bank and the time period, respectively. The variable $P_{i t}$ represents the loan price, calculated as financial and non-financial income. $M C_{i t}$ is the riskadjusted marginal cost. Banks take the risk premium into account when setting loan prices. Thus, a higher mark-up does not necessarily imply lower banking competition, which might be due to an increase in the risk cost (Cruz-García et al., 2017, 2018). Thus, if marginal costs were estimated in the conventional way, the Lerner index estimates would be biased. Therefore, the risk-adjusted marginal cost is estimated as follows:

$$
M C_{i t}=\frac{r_{t}+P D_{i t}-L G D}{1-P D_{i t}-L G D}
$$

where $r_{t}$ is the risk-free interest rate measured as the quarterly average of the three-month Euribor. $P D_{i t}$ is the probability of default, measured as the impairment loss to loan ratio. ${ }^{6} L G D$ is loss given default. Following Jiménez et al.(2013), LGD is assigned the value 45\%, as recommended in the bank capital rules laid down by the Basel Committee.

\subsection{Financial stability indicators: The Z-score and the NPL ratio.}

This paper uses two measures of risk exposure: the natural logarithm of the Z-score and the non-performing loans ratio $\left(N P L_{i t}\right)$. The Z-score, widely used in the financial stability literature (Laeven and Levine, 2009; Liu et al., 2013; Schaeck et al., 2012), is calculated as given:

\footnotetext{
${ }^{6}$ Jiménez et al. (2013), adopting the approach used by Martín-Oliver et al.(2006), estimate the probability of default $\left(P D_{i t}\right)$ using the Bank of Spain's Risk Information Centre (known by its Spanish acronym, CIR). This research uses Bankscope accounting data, since access to the CIR database is not possible.
} 


$$
Z_{i t}=\frac{R O A_{i t}+C A R_{i t}}{\sigma\left(R O A_{i t}\right)}
$$

where $R O A_{i t}$ is the profitability ratio calculated as profits before taxes to total assets; $C A R_{i t}$ is the capital ratio computed as equity capital over total assets; and $\sigma\left(R O A_{i t}\right)$ is the standard deviation of ROA computed as the three-year rolling time window. We estimate a moving standard deviation to allow for the volatility of the denominator.

The Z-score is interpreted as the $\sigma\left(R O A_{i t}\right)$ value needed to absorb the bank's equity capital. In other words, this indicator represents the inverse probability of bank default.

Finally, the non-performing loans ratio $\left(N P L_{i t}\right)$ is calculated as impaired loans over total loans.

\subsection{Empirical specification}

This section presents a discussion on the strategies used to identify and test the hypotheses regarding the impact of the ECB's QE on bank business, competition and financial stability.

The empirical methodology for this study is based on panel data techniques combining cross-section and time series information:

$$
\begin{aligned}
y_{i t}=\beta_{1} M P_{t} \times & \text { Periphery }_{h} \times Q E_{t}+\beta_{2} M P_{t} \times\left(1-\text { Periphery }_{h}\right) \times Q E_{t} \\
& +\beta_{3} M P_{t} \times \text { Periphery }_{h} \times\left(1-Q E_{t}\right) \\
& +\beta_{4} M P_{t} \times\left(1-\text { Periphery }_{h}\right) \times\left(1-Q E_{t}\right) \\
& +\beta_{5} M P_{t} \times \text { Peripher }_{h} \times\left(1-\text { Crisis }_{t}\right) \\
& +\beta_{6} M P_{t} \times\left(1-\text { Periphery }_{h}\right) \times\left(1-\text { Crisis }_{t}\right)+X_{i, t-1}^{\prime} \Phi+v_{i}+\varepsilon_{i t}
\end{aligned}
$$

where $y_{i t}$ denotes the dependent variable for the following indicators:

i. Bank business variables: The first is the proportion of customer loans to total assets $\left(\right.$ LOANTA $\left._{i t}\right)$ which measures the bank's credit supply. We also include the ratio of customer deposits to total assets $\left(D E P T A_{i t}\right)$ to indicate the bank's deposit-gathering capacity (Altavilla et al., 2019).

ii. Banking concentration measures: credit and deposit market concentration are measured using the Herfindhal-Hirschman Index (HHI), which is computed as the squared sum of the market shares of credit and deposits, respectively. Formally, the HHI is calculated as $H H I_{h t}=\sum_{i=1}^{N}\left(M S_{i t}\right)^{2}$, where $M S_{i t}$ is the credit and deposit market shares of each bank $(i)$ in the country in which it operates $(h)$. Then, as a robustness 
check, we include the natural logarithm of the number of banks operating $\left(\operatorname{Ln}\left(\right.\right.$ Banks $\left.\left._{h t}\right)\right)$ in each country $h$, to account for the evolution of competition.

iii. Financial stability indicators: The indicators of interest are the natural logarithm of the $Z$-score $\left(\operatorname{Ln}\left(Z_{i t}\right)\right)$ as calculated in expression (3), and the NPL ratio $\left(N P L_{i t}\right)$.

As for the explanatory variables, the indicator of interest is $M P_{t-1}$, which shows the Eurozone monetary policy stance and comprises the following macroeconomic interest rates: the 1-month Euribor, the 3-month Euribor, and the EONIA (Altavilla et al., 2019; Carbó-

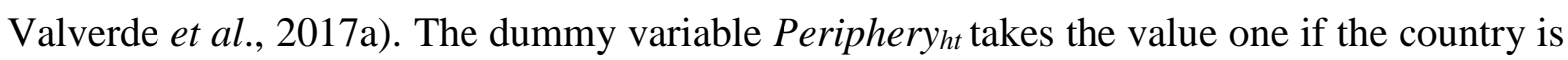
classified as a periphery country, and zero otherwise (Altavilla et al., 2017a,b; Chiesa and Mansilla-Fernández, 2018). ${ }^{7}$ The dummy variable Crisist represents the crisis quarters and breaks the sample down into the pre-crisis period (Crisis $s_{t}=0$ if $t \leq 2007 \mathrm{Q} 4$ ), and the crisis period prior to the beginning of the ECB's QE programme (Crisis $t=1$ if $t \geq 2008 \mathrm{Q} 1$ and $t \leq$ 2015Q1). Lastly, the dummy variable $Q E_{t}$ splits the sample into the period in which interest rates $\left(M P_{t}\right)$ become negative, when $Q E_{t}=1$, and the rest of the sample period when $Q E_{t}=0$. The interpretation of the interaction terms proceeds as follows. The parameter $\beta_{1}\left(\beta_{2}\right)$ represents the impact of $M P_{t}$ after the ECB's QE for the periphery (core) country banks; the parameter $\beta_{3}$ $\left(\beta_{4}\right)$ is the impact of $M P_{t}$ during the crisis period for the periphery (core) country banks; and $\beta_{5}$ $\left(\beta_{6}\right)$ is the impact of $M P_{t}$ before the crisis for the periphery (core) country banks.

The matrix $X_{i, t-1}^{\prime}$ includes the following control variables lagged by one period. Bank size $\left(\operatorname{Ln}\left(T A_{i, t-1}\right)\right)$ is the natural logarithm of bank total assets. The income structure ratio $\left(I N C_{i, t-1}\right)$ is calculated as the proportion of non-interest earnings (operating earnings minus the interest margin) over operating earnings and controls for bank business diversification. The efficiency ratio $\left(E F F_{i, t-1}\right)$, computed as the ratio of operating costs to operating income, controls for bank (in)efficiency. Financial leverage $\left(L E V_{i, t-1}\right)$, computed as the total assets to equity ratio, controls for bank risk-taking behaviour.

Macroeconomic variables are included to control for business cycle effects. The natural logarithm of the GDP $\left(\operatorname{Ln}\left(G D P_{h, t-1}\right)\right)$ denotes the quarterly variation in GDP for each country $(h)$. The Harmonised Index of Consumer Prices $\left(H_{I C P} P_{h, t-1}\right)$ measures the average changeover

\footnotetext{
${ }^{7}$ The periphery countries (Peripheryht) are Cyprus, Greece, Ireland, Italy, Portugal, Slovenia, and Spain, while the core countries (1 - Peripheryht) are Austria, Belgium, Estonia, Finland, France, Germany, Luxembourg, Malta, the Netherlands, and Slovakia (Altavilla et al., 2017b).
} 
time in the prices paid by Eurozone households for consumer goods and services. Finally, Ln(Banksht) controls for the number of competitors in the credit and deposits markets.

Disentangling the transmission channel. We are interested in analysing to determine whether the reduction in the number of competitors might act as a vehicle for the transmission of the unconventional monetary policy stance to credit and deposit supply and banking sector stability. Thus, we estimate the following instrumental variables (IV) model to identify the transmission channel proposed in this article:

$$
\begin{gathered}
y_{i t}=\delta_{0}+\delta_{1} \operatorname{Ln}\left(\widehat{B a n k s}_{h, t-1}\right)+X_{i, t-1}^{\prime} \Lambda+v_{i}+\varepsilon_{i t} \\
\operatorname{Ln}\left(\widehat{B a n k s}_{h, t-1}\right)=\lambda_{1} M P_{t-1}+\lambda_{2} H H I_{i, t-1}+\varpi_{i t}
\end{gathered}
$$

where $y_{i t}$ denotes the set of dependent variables defined above. The variable $\operatorname{Ln}\left(\widehat{B a n k s}_{h, t-1}\right)$ is the predicted value of the natural logarithm of the number of banks in each country $(h)$. The parameter $\lambda_{l}$ denotes the impact of macroeconomic interest rates on the number of banks; and the parameter $\delta_{1}$ captures the effects of the predicted value of $\operatorname{Ln}\left(\widehat{B a n k} s_{h, t-1}\right)$ on $y_{i t}$. The 'indirect' transmission channel is identified if both parameters are statistically significant.

\section{RESULTS}

\subsection{Descriptive statistics}

Table 1 reports the distribution of the variables employed in this study. We observe that the ratio of customer loans to total assets $\left(L O A N T A_{i t}\right)$ on bank balance sheets displays a mean of 58.89 percent with a range of 4.10 percent to 92.85 percent, while the average deposits to total assets ratio $\left(D E P T A_{i t}\right)$ has a mean of 57.91 percent, with a range between 7.46 percent and 98 percent. With respect to the bank concentration indicators, the $\mathrm{HHI}$ for loans $\left(\mathrm{HHI}^{\mathrm{Cr}}{ }_{i t}\right)$ displays an average of 0.37 , with a range between 0.001 and 1.00, whereas the HHI for deposits $\left(H_{H I}{ }^{\text {Dep }}{ }_{i t}\right)$ shows an average of 0.38 and a range of 0.001 to 1.00 . The number of banks $\left(\right.$ Banks $\left._{h t}\right)$ shows an average of 566 and a range of 7 to $2,511 .^{8}$

As for the financial stability variables, the inverse probability of default $\left(\operatorname{Ln}\left(Z_{i t}\right)\right)$ shows a mean value of 1.69 , with a range of -5.90 to 4.96 ; while the non-performing loans ratio $\left(N P L_{i t}\right)$ displays a mean value of 7.48 percent and a range of 0.58 percent to 24.75 percent.

\footnotetext{
${ }^{8}$ To avoid dispersion in the distribution of the number of banks operating in each market (Banksht), we use the natural logarithm of the variable $(\operatorname{Ln}($ Banksht $))$.
} 
Among the macroeconomic variable values, the EONIA $\left(E O N I A_{i t}\right)$ displays a mean value of 1.48 percent, with a range of -0.35 percent to 4.25 percent; the 1-month Euribor $\left(E U R I B O R 1_{i t}\right)$ has a mean value of 1.59 percent, and a range of -.37 percent to 4.53 percent; and the 3 -month Euribor (EURIBOR $3_{i t}$ ) has a mean value of 1.73 percent, with a range of -0.31 percent to 4.98 percent. Finally, 63.34 percent of our sample refers to the crisis period $\left(\right.$ Crisis $\left._{t}\right)$, and 13.33 percent refers to those quarters in which the ECB's unconventional monetary policy was in force $\left(Q E_{t}\right)$.

[Table 1]

To complement the above results, we break the sample down into periphery and core country banks (Altavilla et al., 2017b). In Table 2, we estimate the average and the standard deviation of each key variable for the pre-crisis period (2001Q1 - 2008Q4), the crisis period (2009Q1 2015Q1), and the QE period (2015Q2 - 2016Q4). We observe that the average volume of bank loans $\left(L O A N T A_{i t}\right)$ is comparatively higher after than before the beginning of crisis. However, our results suggest that the loan volume decreases slightly after the QE period, due to the deleveraging process started by the real sector following the onset of the crisis $\left(H_{l}: \beta_{t} \neq 0\right)$. Outstandingly, the results indicate a higher average loan volume for periphery country banks than for core country banks (Chiesa and Mansilla-Fernández, 2018). This difference between the two groups of banks is confirmed by the Hausman test. ${ }^{9}$ As for the volume of deposits gathered by banks $\left(D E P T A_{i t}\right)$, our results reveal that bank customers increasingly turned to savings as the crisis deepened. The $D E P T A_{i t}$ average is relatively noteworthy and statistically significant over the $\mathrm{QE}$ period $\left(H_{l}: \beta_{t} \neq 0\right)$. Surprisingly, we find that periphery country savers held a higher volume of savings than their core country counterparts prior to the crisis (2002Q1 - 2008Q1). However, core country banks began to attract relatively more savings from the onset of the crisis onwards, with this trend increasing in the QE period (2015Q2 - 2016Q4). The Hausman test confirms the difference in the behaviour of the two groups. Our results regarding bank concentration suggest a relative increase in the $H H I$ for credit and deposits after the onset of the crisis (2009Q1 - 2015Q1), returning to a more moderate average following implementation of the QE (2015Q2 - 2016Q4). Interestingly, the results display a decreasing trend in the number of banks for the study period as a whole, with the deepest dip appearing in the QE period. This result is consistent with previous papers supporting the view that, in a

\footnotetext{
${ }^{9}$ The Hausman specification test evaluates the consistency of an estimator $\left(b_{1}\right)$ compared to an alternative $\left(b_{2}\right)$, under the null that both are consistent, but $b_{1}$ is efficient. The Hausman statistic is given as follows: $H=\left(\mathrm{b}_{1}-\mathrm{b}_{2}\right)^{\prime}\left[\operatorname{Var}\left(\mathrm{b}_{1}\right)-\operatorname{Var}\left(\mathrm{b}_{2}\right)\right]^{-1}\left(\mathrm{~b}_{1}-\right.$ b2) $\sim X_{n}$, where degrees of freedom $(n)$ are the number of variables.
} 
scenario of negative interest rates, bank mergers were a means to increase profitability and extract monopoly rents (Andreeva and Garcia-Posada, 2019).

Finally, we also observe that financial stability gradually weakens as the crisis deepens. The inverse probability of banks' default $\left(\operatorname{Ln}\left(Z_{i t}\right)\right)$ exhibits a decreasing trend throughout the sample period, with banks in core countries showing significantly higher index values than those of periphery countries. Therefore the trend in the volume of impaired loans $\left(N P L_{i t}\right)$ was increasing; with the periphery country banks showing higher volumes due to the deterioration of their macroeconomic conditions (Ghosh, 2017; Grigoli et al., 2018), and a legacy of risky loans threatening their financial stability (Aiyar et al., 2015).

[Table 2]

\subsection{Repercussions of the ECB's QE on lending and deposits}

This section discusses the econometric results that prove Hypothesis 1. Table 3 displays the regression coefficients for expression (4). The hypothesis for this section is tested using the fixed-effects estimator. Estimates for the loan supply $\left(L O A N T A_{i t}\right)$ are shown in columns (1)(3), and estimates for deposits $\left(D E P T A_{i t}\right)$ in columns (4)-(6). It can be seen from the negative significant estimates that a $1 \%$ increase in the 1-month Euribor causes $L O A N T A_{i t}$ and DEPTA to diminish by $0.078 \%$ and $0.226 \%$, respectively, for the periphery country banks, once interest rates turn negative $\left(H_{0}: \beta_{1}=0\right)$. Interestingly, we find no empirical evidence of the sensitivity of loan supply to negative interest rates for the core country banks (see Brunnermeier and Kobby, 2019). However, our results do suggest that such sensitivity among depositors in core countries causes $D E P T A_{i t}$ to increase by $0.160 \%$ on average. Although, the impacts of negative interest rates on banks' deposit ratio $\left(D E P T A_{i t}\right)$ appear to vary between periphery and core country banks, we find no empirical evidence to prove that the ECB's QE impacted differently in the two 'Europes' $\left(H_{1}: \beta_{1} \neq \beta_{2}\right)$. The estimates for the pre-crisis period and the control variables have the expected sign and significance levels. The results of this study suggest that negative interest rates increased the loan supply for the periphery country banks due to reductions in funding costs (Berger et al., 2017; Molyneux et al., 2019a,b).Our results are therefore in line with previous studies supporting the theory that negative interest rates increase deposits by driving demand for liquidity and safe assets (Altavilla et al., 2019).

[Table 3] 


\subsection{Repercussions of the ECB's QE on bank concentration}

One might argue that the unconventional monetary policy could have modified the configuration of the Eurozone banking market (Hypothesis 2). Previous studies have argued that negative interest rates substantially reduced profitability in the Eurozone banks, driving many toward mergers as a means to obtain synergies and economies of scale (Andreeva and Garcia-Posada, 2019). This study contributes to the literature by demonstrating that monetary policy can wield influence over banking concentration.

Table 4 reports the random effects estimates after rejecting the null in the Hausman test. Columns (1)-(3) give the estimates of the regression of the HHI for lending markets $\left(\mathrm{HHI}^{\mathrm{Cr}}{ }_{i t}\right)$, which suggest that a variation in macroeconomic interest rates (1-month Euribor, 3-month Euribor, and EONIA) increases the concentration in lending markets. Interestingly, we do find that concentration in lending markets becomes relatively more sensitive to negative interest rates, i.e. during the ECB's QE periods $\left(H_{1}: \beta_{1} \neq 0 ; H_{1}: \beta_{2} \neq 0\right)$. Importantly, this result is economically more significant for periphery country banks than for core country banks $\left(H_{1}: \beta_{1}\right.$ $\neq \beta_{2}$ ). This result implies that concentration in lending supply diminishes insofar as interest rates become negative. In other words, funding - or input-costs for banks diminish due to the ECB's QE, vertically squeezing the marginal costs of loans. Thus, banks are able to provide more, and cheaper, loans than before. However, the estimates on $\beta_{3}$ and $\beta_{4}$ are not statically significant owing to the reduction in loan demand associated with deteriorating macroeconomic conditions and the processes of deleveraging in the real sector during the crisis period (2009Q1 - 2015Q1) (BdE, 2017; Ghosh, 2017). Finally, the estimates on $\beta_{5}$ and $\beta_{6}$ display the expected sign and level of significance, which is lower than the estimates on $\beta_{1}$ and $\beta_{2}$, demonstrating that the concentration of the lending market becomes more sensitive to negative interest rates. Interestingly, periphery country banks are relatively more sensitive to changes in interest rates $\left(H_{1}: \beta_{1} \neq \beta_{2}\right)$.

\section{[Table 4]}

The second question that this subsection endeavours to answer is whether negative interest rates influence the Eurozone deposits markets (columns (4)-(6)). The results show that increases in macroeconomic interest rates drive concentration in the deposits market. In fact, the positive and significant estimates on $\beta_{1}$ and $\beta_{2}$, suggest a sharp fall in deposits market concentration as interest rates dropped into negative territory. Interestingly, we find not only that the ECB's QE increased the sensitivity of $\mathrm{HHI}^{\mathrm{Dep}}{ }_{h t}$, but also that the implications were 
economically more significant for periphery country banks than for core country banks $\left(H_{1}: \beta_{1}\right.$ $\neq \beta_{2}$ ). Our results suggest that negative interest rates drove banks to compete more intensely for deposits as a means of safe funding (Altavilla et al., 2019). The estimates for previous periods and the control variables carry the expected sign and level of significance. Finally, the estimates shown in columns (7)-(8) confirm that the monetary policy stance may condition the number of banks competing in each Eurozone market $\left(\operatorname{Ln}\left(\right.\right.$ Banks $\left.\left._{h t}\right)\right)$. Positive and significant estimates on all the coefficients $\left(H_{1}: \beta_{i} \neq 0\right)$ suggest that the number of competitors in banking markets increases as interest rates rise. Newly-created banks appear in the market when macroeconomic interest rates are high enough to enable profitability $\left(H_{1}: \beta_{i} \neq 0\right)$. Consistently, we find that the number of banks decreased significantly following the implementation of the ECB's QE program, i.e., after interest rates became negative. These results are in line with previous studies demonstrating that banks merged at national levels to increase in size and pursue economies of scale and monopoly rents (Andreeva and Garcia-Posada, 2019).

[Table 5]

The results presented above are robust to the inclusion of instrumental variables (IV), as shown in expressions (5a) and (5b), to control for the functioning of the 'indirect channel' (Andreeva and Garcia-Posada, 2019). The IV estimates are reported in Table 5. The sign and magnitude of the IV estimator support the argument that the monetary policy stance might condition the number of competitors in banking markets, which might then drive the demand for loans and supply of deposits in the real sector. The standard Sargan's test rejects the null and demonstrates the orthogonality of the instruments used in this investigation. Valid inference is also ensured, since standard errors are robust to heteroscedasticity, and clustered at the specialization level.

\subsection{The repercussions of the ECB's QE on financial stability}

The next question to arise in the light of the above results concerns the impact of the changes caused by the ECB's QE -that is, negative interest rates- on financial stability (Hypothesis 3). Previous studies have shown that concentration might impact on stability for the banking sector (Arping, 2019; Jiménez et al., 2013; Martinez-Miera and Repullo, 2010). This study contributes to the literature by demonstrating that reductions in banking competition due to negative interest rates undermine the overall stability of the banking industry. Table 6 reports the OLS estimates for panel data with fixed effects. 
Column (1) gives the estimates of the regression of the risk-adjusted Lerner index on (inverse) bank default probability, which suggest that reduced competition impacted negatively on stability after implementation of the ECB's QE programme. They further reveal that reduced competition increased the volume of impaired loans following the unconventional monetary policy measures (column (2)). It should be noted that periphery countries are comparatively more sensitive to the impact of changes in competition on bank risk, and that the impact gradually reduces with decreasing loan demand or increasing deleverage.

[Table 6]

Although the negative interest rates induced by the ECB's QE program reduce marginal costs, thus enabling banks to increase their output, they also have a negative impact on prices for financial intermediation services, thus reducing their interest margins and profitability. As a result, banks become weakened; as does the stability of the sector as a whole. Previous literature relating financial stability to competition claims that banks tend to reduce their lending standards and take on more credit risk. The results of this study suggest that reduced competition causes an upsurge in banks' risk-taking behaviour, although reductions in loan demand and deleverage in the real sector attenuate the impact on the NPL ratio. Interestingly, we do find that the competition-stability relationship is more intense for the periphery country banks than for the core country banks (Allen and Gale, 2004; Coccorese, 2004, 2009).

We test the robustness of the results presented above by substituting Lerner $_{i t}$ with the natural logarithm of the number of banks operating in each country $(\operatorname{Ln}($ Banksht $))$. We also address possible endogeneity problems by including IV to test whether the transmission channel under investigation also operates for financial stability. The results of the IV estimator are shown in Table 7. The sign and magnitude of the estimates display the expected values and level of significance, demonstrating that monetary policy can impact on financial stability and bank risk-taking behaviour by modifying the number of competitors in domestic markets. The Sargan's test validates the orthogonality of the instruments.

[Table 7]

\section{CONCLUSIONS}

This paper analyses the relationship between the ECB's QE, materialized in negative interest rates, and the degree of concentration in the Eurozone banking markets. We construct 
a unique dataset by combining accounting data from Bankscope (Bureau van Dijk) and macroeconomic data from the Thomson Reuters Datastream for each country of the Eurozone.

The main finding of this study is that negative interest rates affect banks' loans and deposits supply and financial stability (Brunnermeier and Kobby, 2019; Drechsler et al., 2017) through reductions in the degree of banking competition, also known as the 'indirect channel' (Andreeva and Garcia-Posada, 2019). Recent research demonstrates that negative interest rates erode banks' assets values and reduce their interest margins (Phil Molyneux et al., 2019a,b). As a consequence of this, the Eurozone banks initiated processes of integration and upsize to gain economies of scale. The results of this study reveal that gains in cost-efficiency and relatively cheaper funding increase loan and deposits supply, and concentration in both markets (Arteta et al., 2016; Chaudron, 2018). Furthermore, financial stability is weakened by profit reductions and the accumulation of NPLs, in line with the 'competition-stability' view (Allen and Gale, 2004; Arping, 2019; Coccorese, 2004, 2009). Specifically, we are able to conclude that this effect is economically more significant for banks operating in the periphery countries of the Eurozone.

To the best of our knowledge, this is one of the first studies attempting to disentangle the workings of the (unconventional) monetary policy-banking competition-lending and deposits supply channel. The results are robust to endogeneity tests and different measures of banking competition. The repercussions of the holdings of sovereign debt on banks' balance sheets for banking competition is an issue that remains for future research.

\section{Acknowledgements:}

We are indebted to the Editor (Juan E. Trinidad Segovia) and two anonymous referees for their thorough review, comments and suggestions, which significantly contributed to improving the quality of this paper. We would also like to express our gratitude to Marco Barrenechea Méndez, HéctorGarcía Montero, and Vicente Ríos Ibáñez for their remarks. José Manuel Mansilla Fernández gratefully acknowledges financial support from ECO2016-77631R (Ministerio de Economía y Competitividad). 


\section{REFERENCES}

AIYAR, S.; BERGTHALER, W.; GARRIDO, J.; ILYINA, A.; JOBST, A.; KANG, K.; ... MORETTI, M. (2015). A Strategy for Resolving Europe's Problem Loans. https://doi.org/http://dx.doi.org/10.5089/9781513591278.006

ALLEN, F.and GALE, D. (2004). "Competition and Financial Stability". Journal of Money, Credit and Banking, 36(3), pp. 453-480. Retrieved from http://www.jstor.org/stable/3838946

ALTAVILLA, C.; BURLON, L.; GIANNETTI, M.and HOLTON, S. (2019). Is there a zero lower bound? The effects of negative policy rates on banks and firms (No. 2289 / June 2019). Retrieved

from https://www.ecb.europa.eu/pub/pdf/scpwps/ecb.wp2289 1a3c04db25.en.pdf

ALTAVILLA, C.; GIACOMINI, R.and RAGUSA, G. (2017a). "Anchoring the yield curve using survey expectations". Journal of Applied Econometrics, 32(6), pp. 1055-1068. https://doi.org/10.1002/jae.2588

ALTAVILlA, C.; PAGANO, M.and SIMONELLI, S. (2017b). "Bank Exposures and Sovereign Stress Transmission*". Review of Finance, 21(6), pp. 2103-2139. https://doi.org/10.1093/rof/rfx038

ANDREEVA, D.and GARCIA-POSADA, M. (2019). The Impact of the ECB's Targeted LongTerm Refinancing Operations on Banks' Lending Policies: The Role of Competition. SSRN Electronic Journal. https://doi.org/10.2139/ssrn.3330525

ARPING, S. (2019). "Competition and risk taking in banking: The charter value hypothesis revisited". Journal of Banking \& Finance, 107, 105609. https://doi.org/10.1016/J.JBANKFIN.2019.105609

ARTETA TASKIN, C.and TEMEL, M. A. K. M. S. (2016). Negative Interest Rate Policies: Sources and Implications. In Policy Research Working Papers. https://doi.org/doi:10.1596/1813-9450-7791

BdE. (2017). Report on the financial and banking crisis in Spain, 2008-2014. Retrieved from https://www.bde.es/bde/en/secciones/informes/Otras_publicacio/informe-sobre-la/

BERGER, A. N.; BLACK, L. K.; BOUWMAN, C. H. S.and DLUGOSZ, J. (2017). "Bank loan supply responses to Federal Reserve emergency liquidity facilities". Journal of Financial Intermediation, 32, pp. 1-15. https://doi.org/10.1016/J.JFI.2017.02.002

BERGER, A. N.and DEYOUNG, R. (1997). "Problem loans and cost efficiency in commercial banks". Journal of Banking \& Finance, 21(6), pp. 849-870. https://doi.org/https://doi.org/10.1016/S0378-4266(97)00003-4

BOUWMAN, C. H. S.and MALMENDIER, U. (2015). "Does a Bank's History Affect Its RiskTaking?"The American Economic Review, 105(5), pp. 321-325. Retrieved from http://www.jstor.org/stable/43821901

BOWMAN, D.; CAI, F.; DAVIES, S.and KAMIN, S. (2015). "Quantitative easing and bank lending: Evidence from Japan". Journal of International Money and Finance, 57, pp. 1530. https://doi.org/https://doi.org/10.1016/j.jimonfin.2015.05.002

BOYD, J. H.and DE NICOLÒ, G. (2005). "The Theory of Bank Risk Taking and Competition Revisited". The Journal of Finance, 60(3), pp. 1329-1343. https://doi.org/10.1111/j.15406261.2005.00763.x 
BRUNNERMEIER, M. K.andKOBBY, Y. (2019). The Reversal Interest Rate. Retrieved from https://scholar.princeton.edu/markus/publications/reversal-interest-rate-effective-lowerbound-monetary-policy

BRUNNERMEIER, M. K.andSANNIKOV, Y. (2016). The I Theory of Money (No. 22533). https://doi.org/10.3386/w22533

BUSCH, R.and MEMMEL, C. (2017). "Banks' net interest margin and the level of interest rates". Credit and Capital Markets - Kredit Und Kapital, 50(3), pp. 363-392. https://doi.org/https://doi.org/10.3790/ccm.50.3.363

CARBÓ-VALVERDE, S.; MANSILLA-FERNÁNDEZ, J. M.and RODRÍGUEZ-FERNÁNDEZ, F. (2017a). "Monetary policy, implicit interest rate, and relative net trade credit". Revista de Economia Aplicada, XXV(73), pp 21-54.

CARBÓ-VALVERDE, S.; MANSILLA-FERNÁNDEZ, J. M.and RODRÍGUEZ-FERNÁNDEZ, F. (2017b). "The effects of bank market power in short-term and long-term firm credit availability and investment". Revista Espanola de Financiacion y Contabilidad, 46(1), pp. 1-27. https://doi.org/10.1080/02102412.2016.1242239

CARBÓ, S.; RODRÍGUEZ, F.and UDELL, G. F. (2009). "Bank Market Power and SME Financing Constraints". Review of Finance, 13(2), pp. 309-340. https://doi.org/10.1093/rof/rfp003

CHAKRABORTY, I.; GOLDSTEIN, I.and MACKINLAY, A. (2019). "Monetary Stimulus and Bank Lending". Journal of Financial Economics, Forthcoming.

CHAUDRON, R. F. D. D. (2018). "Bank's interest rate risk and profitability in a prolonged environment of low interest rates". Journal of Banking \& Finance, 89, pp. 94-104. https://doi.org/https://doi.org/10.1016/j.jbankfin.2018.01.007

CHIESA, G.and MANSILLA-FERNÁNDEZ, J. M. (2018). "Disentangling the transmission channel NPLs-cost of capital-lending supply". Applied Economics Letters, pp. 1-6. https://doi.org/10.1080/13504851.2018.1558335

CLAESSENS, S.; COLEMAN, N.and DONNELLY, M. (2018). "“Low-For-Long” interest rates and banks' interest margins and profitability: Cross-country evidence". Journal of Financial Intermediation, 35, pp. 1-16. https://doi.org/https://doi.org/10.1016/j.jfi.2017.05.004

COCCORESE, P. (2004). "Banking competition and macroeconomic conditions: \{a\} disaggregate analysis". Journal of International Financial Markets, Institutions and Money, 14(3), pp. 203-219. https://doi.org/http://dx.doi.org/10.1016/j.intfin.2003.07.001

COCCORESE, P. (2008). "Bank competition and regional differences". Economics Letters, 101(1), pp. 13-16. https://doi.org/http://dx.doi.org/10.1016/j.econlet.2008.03.019

COCCORESE, P. (2009). "Market power in local banking monopolies". Journal of Banking \& Finance, 33(7), pp. 1196-1210. https://doi.org/http://dx.doi.org/10.1016/j.jbankfin.2008.12.013

CRUZ-GARCÍA, P.; FERNÁNDEZ DE GUEVARA, J.and MAUDOS, J. (2017). "The evolution of market power in European banking". Finance Research Letters, 23, pp. 257-262. https://doi.org/https://doi.org/10.1016/j.frl.2017.06.012 
CRUZ-GARCÍA, P.; FERNÁNDEZ DE GUEVARA, J.and MAUDOS, J. (2018). "Concentración y competencia bancarias en España: El impacto de la crisis y de la reestructuración". Revista de Estabilidad Financiera - Financial Stability Review, 5(34), pp. 57-76. Retrieved from https://www.bde.es/f/webbde/GAP/Secciones/Publicaciones/InformesBoletinesRevistas/R evistaEstabilidadFinanciera/18/MAYO/Articulo_Cruz_Guevara_Maudos-en.pdf

CÚRDIA, V.and WOODFORD, M. (2011). "The central-bank balance sheet as an instrument of monetarypolicy". Journal of Monetary Economics, 58(1), pp. 54-79. https://doi.org/https://doi.org/10.1016/j.jmoneco.2010.09.011

DEGRYSE, H.and ONGENA, S. (2008). "\{CHAPTER $\} 15$ - Competition and Regulation in the Banking Sector: A Review of the Empirical Evidence on the Sources of Bank Rents". In A. V Thakor \& A. W. A. Boot (Eds.), Handbook of Financial Intermediation and Banking, pp. 483-554. https://doi.org/http://dx.doi.org/10.1016/B978-044451558-2.50023-4

DEL NEGRO, M.; EGGERTSSON, G.; FERRERO, A.and KIYOTAKI, N. (2017). "The Great Escape? A Quantitative Evaluation of the Fed's Liquidity Facilities". American Economic Review, 107(3), pp. 824-857. https://doi.org/10.1257/aer.20121660

DRECHSLER, I.; SAVOV, A.and SCHNABL, P. (2017). "The Deposits Channel of Monetary Policy*". The Quarterly Journal of Economics, 132(4), pp. 1819-1876. https://doi.org/10.1093/qje/qjx019

EGGERTSSON, G. B., and WOODFORD, M. (2003). "The Zero Bound on Interest Rates and Optimal Monetary Policy". Brookings Papers on Economic Activity, 2003(1), pp. 139-211. Retrieved from http://www.jstor.org/stable/1209148

FERNÁNDEZ DE GUEVARA, J.; MAUdOS, J. and PÉREZ, F. (2005). "Market Power in European Banking Sectors". Journal of Financial Services Research, 27(2), pp. 109-137. https://doi.org/10.1007/s10693-005-6665-z

GOETZ, M.R. (2018). "Competition and bank stability". Journal of Financial Intermediation, 35, Part A, pp. 57-69. https://doi.org/10.1016/j.jfi.2017.06.001

GHOSH, A. (2017). "Sector-specific analysis of non-performing loans in the US banking system and their macroeconomic impact". Journal of Economics and Business, 93, pp. 29-45. https://doi.org/10.1016/J.JECONBUS.2017.06.002

GRIGOLI, F.; MANSILLA, M.and SALDÍAS, M. (2018). "Macro-financial linkages and heterogeneous non-performing loans projections: An application to Ecuador". Journal of Banking \& Finance, 97, pp. 130-141. https://doi.org/10.1016/J.JBANKFIN.2018.09.023

HEIDER, F.; SAIDI, F.and SCHEPENS, G. (2019). "Life below Zero: Bank Lending under Negative Policy Rates*". The Review of Financial Studies. https://doi.org/10.1093/rfs/hhz016

IJTSMA, P.; SPIERDIJK, L.and SHAFFER, S. (2017). "The concentration-stability controversy in banking: New evidence from the EU-25". Journal of Financial Stability, 33(December), pp. 273-284. https://doi.org/http://dx.doi.org/10.1016/j.jfs.2017.06.003

JIMÉNEZ, G.; LOPEZ, J. A.and SAURINA, J. (2013). "How does competition affect bank risktaking?"Journal of Financial Stability, 9(2), pp. 185-195. https://doi.org/10.1016/J.JFS.2013.02.004 
LAEVEN, L.and LEVINE, R. (2009). "Bank governance, regulation and risk taking". Journal of Financial Economics, 93(2), pp. 259-275. https://doi.org/http://dx.doi.org/10.1016/j.jfineco.2008.09.003

LIU, H.; MOLYNEUX, P.and WILSON, J. O. S. (2013). "Competition and stability in European banking: A regional analysis*". The Manchester School, 81(2), pp. 176-201. https://doi.org/10.1111/j.1467-9957.2011.02285.x

LOPEZ, J. A.; ROSE, A. K. and SPIEGEL, M. (2018). Why Have Negative Nominal Interest Rates Had Such a Small Effect on Bank Performance? Cross Country Evidence (No. 13010).

MARTINEZ-MIERA, D.and REPULLO, R. (2010). "Does Competition Reduce the Risk of Bank Failure?"Review of Financial Studies, 23(10), pp. 3638-3664. https://doi.org/10.1093/rfs/hhq057

MOLYNEUX, P.; REGHEZZA, A.; THORNTON, J.and XIE, R. (2019a). "Did Negative Interest Rates Improve Bank Lending?"Journal of Financial Services Research. https://doi.org/10.1007/s10693-019-00322-8

MOLYNEUX, P.; REGHEZZA, A.and XIE, R. (2019b). "Bank margins and profits in a world of negative rates". Journal of Banking \& Finance, 107, 105613. https://doi.org/https://doi.org/10.1016/j.jbankfin.2019.105613

OLIVER, A. M.; FUMÁS, V. S.and SAURINA, J. (2006). "Risk premium and market power in credit markets". Economics Letters, 93(3), pp. 450-456. https://doi.org/10.1016/J.ECONLET.2006.06.021

ONGENA, S. R. G.and POPOV, A. A. (2009). Interbank Market Integration, Bank Competition, and Loan Rates. Retrieved from http://dx.doi.org/10.2139/ssrn.1339856

RODNYANSKY, A.and DARMOUNI, O. M. (2017). "The Effects of Quantitative Easing on Bank Lending Behavior". The Review of Financial Studies, 30(11), pp. 3858-3887. https://doi.org/10.1093/rfs/hhx063

SCHAECK, K.; CIHAK, M., MAECHLER, A.and STOLZ, S. (2012). "Who Disciplines Bank Managers?"Review of Finance, 16(1), pp. 197-243. https://doi.org/10.1093/rof/rfr010

VANHOOSE, D. (2017). The Industrial Economics of Banking. In VanHoose, D.The Industrial Organization of Banking: Bank Behavior, Market Structure, and Regulation (pp. 47-88). https://doi.org/10.1007/978-3-662-54326-9_3

WALLACE, N. (1981). "A Modigliani-Miller Theorem for Open-Market Operations". The American Economic Review, 71(3), pp. 267-274. Retrieved from http://www.jstor.org/stable/1802777

ZHANG, D.; CAI, J.; DICKINSON, D. G.and KUTAN, A. M. (2016). "Non-performing loans, moral hazard and regulation of the Chinese commercial banking system". Journal of Banking \& Finance, 63, pp. 48-60. https://doi.org/10.1016/J.JBANKFIN.2015.11.010 


\section{Figure 1}

Evolution of interbank interest rates, and the distribution of the number of banks in the Eurozone.
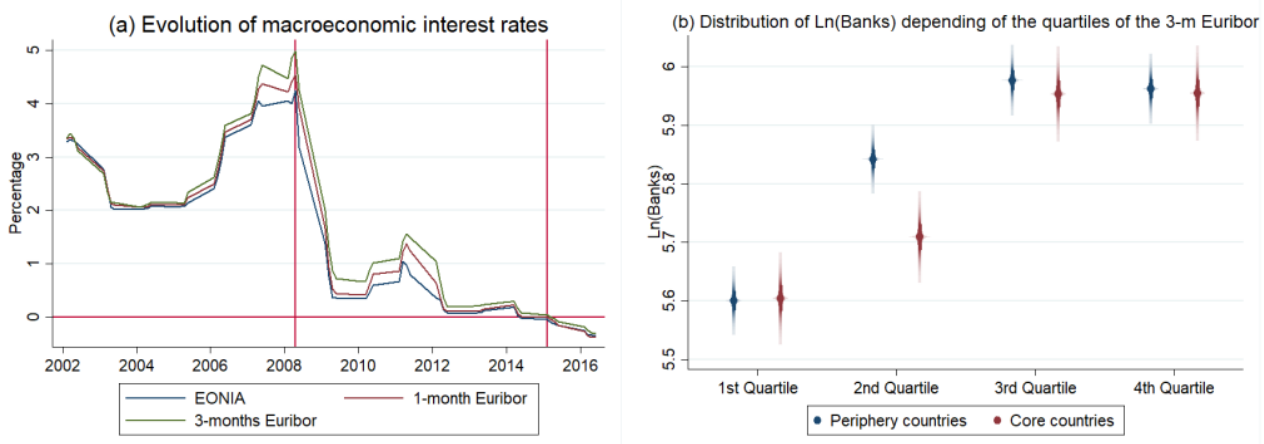

Notes: Data drawn by the authors from Thomson Reuters Datastream and Bankscope (Bureau van Dijk). The variable $\operatorname{Ln}\left(\right.$ Banks $\left._{h t}\right)$ denotes the natural logarithm of the number of banks in each country $(h)$. Figure 1.a depicts the evolution of EONIA, the 1-month Euribor and the 3-month Euribor. Vertical lines represent the beginning of the Full Allotment Operations (October 2008) and the Asset Purchase Programme (March 2015), respectively. Figure 1.b plots the distribution of $L n\left(B a n k s_{h t}\right.$ ) for banks operating in the periphery and core countries based on their 3-month Euribor quartiles. The central point represents the estimated mean value, while the limits show the 95 percent confidence interval. 
Table 1

Summary statistics

\begin{tabular}{|c|c|c|c|c|c|c|c|c|}
\hline & $\mathbf{N}$ & Mean & St.Dev. & Min. & Pc. 25 & $\begin{array}{c}\text { Media } \\
\text { n }\end{array}$ & Pc.75 & Max. \\
\hline $\operatorname{LOANTA}_{i t}$ & $\begin{array}{l}11,46 \\
0\end{array}$ & 0.58888 & 0.2127 & $\begin{array}{l}0.041 \\
0\end{array}$ & $\begin{array}{l}0.458 \\
3\end{array}$ & 0.6315 & $\begin{array}{l}0.757 \\
6\end{array}$ & 0.9285 \\
\hline$D_{E P T A} i t$ & $\begin{array}{l}11,46 \\
0\end{array}$ & 0.57913 & 0.2321 & $\begin{array}{l}0.074 \\
6\end{array}$ & $\begin{array}{l}0.404 \\
9\end{array}$ & 0.5834 & $\begin{array}{l}0.772 \\
7\end{array}$ & 0.9800 \\
\hline$H H I^{C r}{ }_{i t}$ & $\begin{array}{l}11,46 \\
0\end{array}$ & 0.37115 & 0.3188 & $\begin{array}{l}0.000 \\
0\end{array}$ & $\begin{array}{l}0.000 \\
0\end{array}$ & 0.3580 & $\begin{array}{l}0.531 \\
7\end{array}$ & 1.0000 \\
\hline$H H I^{D e p}{ }_{i t}$ & $\begin{array}{l}11,46 \\
0\end{array}$ & 0.37895 & 0.3222 & $\begin{array}{l}0.000 \\
0\end{array}$ & $\begin{array}{l}0.000 \\
0\end{array}$ & 0.35350 & $\begin{array}{l}0.522 \\
0\end{array}$ & 1.0000 \\
\hline Banksht & $\begin{array}{l}11,46 \\
0\end{array}$ & $\begin{array}{l}566.103 \\
7\end{array}$ & $\begin{array}{l}507.104 \\
4\end{array}$ & 7.00 & $\begin{array}{l}164.0 \\
0\end{array}$ & 462.00 & $\begin{array}{l}798.0 \\
0\end{array}$ & $\begin{array}{l}2,511 . \\
0\end{array}$ \\
\hline Ln(Banksht $)$ & $\begin{array}{l}11,46 \\
0\end{array}$ & 5.8130 & 1.2214 & $\begin{array}{l}1.946 \\
0\end{array}$ & 5.099 & 6.1355 & $\begin{array}{l}6.682 \\
1\end{array}$ & 7.8284 \\
\hline $\ln \left(Z_{i t}\right)$ & $\begin{array}{l}11,46 \\
0\end{array}$ & 1.6915 & 0.9213 & $\begin{array}{l}5.895 \\
3\end{array}$ & $\begin{array}{l}1.136 \\
3\end{array}$ & 1.6624 & $\begin{array}{l}2.243 \\
0\end{array}$ & 4.9625 \\
\hline$N P L_{i t}$ & $\begin{array}{l}11,46 \\
0\end{array}$ & 0.0748 & 0.0659 & $\begin{array}{l}0.005 \\
8\end{array}$ & $\begin{array}{l}0.027 \\
2\end{array}$ & 0.0528 & $\begin{array}{l}0.100 \\
0\end{array}$ & 0.2475 \\
\hline$E_{O N I A}$ & $\begin{array}{l}11,46 \\
0\end{array}$ & 1.4882 & 1.4554 & $\begin{array}{l}- \\
0.348 \\
5\end{array}$ & $\begin{array}{l}0.123 \\
0\end{array}$ & 1.0087 & $\begin{array}{l}2.733 \\
7\end{array}$ & 4.2527 \\
\hline$\underset{t}{E U R I B O R 1}$ & $\begin{array}{l}11,46 \\
0\end{array}$ & 1.5995 & 1.5058 & $\begin{array}{l}- \\
0.371 \\
5\end{array}$ & $\begin{array}{l}0.156 \\
6\end{array}$ & 1.3121 & $\begin{array}{l}2.744 \\
2\end{array}$ & 4.5394 \\
\hline$\underset{t}{E U R I B O R 3}$ & $\begin{array}{l}11,46 \\
0\end{array}$ & 1.7394 & 1.5281 & $\begin{array}{l}- \\
0.312 \\
4\end{array}$ & $\begin{array}{l}0.253 \\
7\end{array}$ & 1.5284 & $\begin{array}{l}2.843 \\
0\end{array}$ & 4.9817 \\
\hline Crisis $_{t}$ & $\begin{array}{l}11,46 \\
0\end{array}$ & 0.63333 & 0.4819 & $\begin{array}{l}0.000 \\
0\end{array}$ & $\begin{array}{l}0.000 \\
0\end{array}$ & 1.0000 & $\begin{array}{l}1.000 \\
0\end{array}$ & 1.0000 \\
\hline$Q E_{t}$ & $\begin{array}{l}11,46 \\
0\end{array}$ & 0.13333 & 0.3399 & $\begin{array}{l}0.000 \\
0\end{array}$ & $\begin{array}{l}0.000 \\
0\end{array}$ & 0.0000 & $\begin{array}{l}0.000 \\
0\end{array}$ & 1.0000 \\
\hline
\end{tabular}

Notes: $i, t$ and $h$ subscripts refer to bank, time and country, respectively. 
Table 2

Means of the study variables by periods of analysis. Standard errors in parentheses.

\begin{tabular}{|c|c|c|c|c|c|c|}
\hline & & $(2002 Q 1-2008 Q 4)$ & $(2009 Q 1-2015 Q 1)$ & $(2015 Q 2-2016 Q 4)$ & $\begin{array}{c}\text { F-test } \\
{[p \text {-value }]}\end{array}$ & $\begin{array}{c}\text { Hausman test } \\
{[p \text {-value }]}\end{array}$ \\
\hline \multirow[t]{2}{*}{ LOANTA $_{i t}$} & Core & $0.544^{* * * *}(0.008)$ & $0.574^{* * * *}(0.006)$ & $0.549^{* * *}(0.013)$ & 0.0000 & 0.0000 \\
\hline & Periphery & $0.631^{* * *}(0.009)$ & $0.658^{* * *}(0.007)$ & $0.650^{* * * *}(0.014)$ & 0.0000 & \\
\hline \multirow[t]{2}{*}{$D E P T A_{i t}$} & Core & $0.535^{* * *}(0.010)$ & $0.588^{* * *}(0.007)$ & $0.647^{* * *}(0.015)$ & 0.0000 & 0.0000 \\
\hline & Periphery & $0.605^{* * *}(0.010)$ & $0.553^{* * *}(0.007)$ & $0.615^{* * * *}(0.015)$ & 0.0000 & \\
\hline \multirow[t]{2}{*}{$H H I^{C{ }_{i t}}$} & Core & $0.327^{* * *}(0.005)$ & $0.414^{* * *}(0.006)$ & $0.367^{* * *}(0.011)$ & 0.0000 & 0.0000 \\
\hline & Periphery & $0.343^{* * * *}(0.007)$ & $0.424^{* * *}(0.007)$ & $0.368^{* * *}(0.014)$ & 0.0000 & \\
\hline \multirow[t]{2}{*}{$H H I^{D e p}{ }_{i t}$} & Core & $0.326^{* * * *}(0.005)$ & $0.430^{* * * *}(0.006)$ & $0.383^{* * *}(0.011)$ & 0.0000 & 0.0000 \\
\hline & Periphery & $0.343^{* * *}(0.007)$ & $0.438^{* * *}(0.008)$ & $0.368^{* * *}(0.014)$ & 0.0000 & \\
\hline \multirow[t]{2}{*}{ Banksht } & Core & $725.652^{* * *}(9.402)$ & $563.042^{* * *}(9.643)$ & $471.303^{* * *}(18.223)$ & 0.0000 & 0.0000 \\
\hline & Periphery & $462.743^{* * *}(6.333)$ & $404.076^{* * *}(6.579)$ & $322.696^{* * *}(12.433)$ & 0.0000 & \\
\hline \multirow[t]{2}{*}{$\operatorname{Ln}\left(Z_{i t}\right)$} & Core & $1.939^{* * *}(0.036)$ & $1.710^{* * * *}(0.026)$ & $1.593^{* * *}(0.056)$ & 0.0000 & 0.0000 \\
\hline & Periphery & $1.774^{* * *}(0.051)$ & $1.375^{* * *}(0.037)$ & $1.333^{* * *}(0.084)$ & 0.0000 & \\
\hline \multirow[t]{2}{*}{$N P L_{i t}$} & Core & $0.035^{* * *}(0.004)$ & $0.071^{* * * *}(0.002)$ & $0.058^{* * *}(0.004)$ & 0.0000 & 0.0000 \\
\hline & Periphery & $0.043^{* * * *}(0.004)$ & $0.099^{* * *}(0.003)$ & $0.152^{* * *}(0.006)$ & 0.0000 & \\
\hline
\end{tabular}

Note: This table splits the sample into two groups: Core country banks (Periphery $\left.y_{h}=0\right)$ and periphery country banks $($ Periphery $=1)$. The test is conducted for the pre-crisis period (2002Q1 - 2008Q4), the crisis period (2009Q1 - 2015Q1), and the QE period (2015Q2 - 2016Q4). All the variables are defined in Table 1 . The coefficients are the mean values, while the standard error is given in parentheses. The F-test checks for changes in the variable between sub-periods. The Hausman test checks for differences between the core and periphery country banks. The $p$ value of the F-test and the Hausman test are shown in the sixth and seventh columns, respectively. *.**.***, denote minimum $10 \%, 5 \%, 1 \%$ significance, respectively. 
Table 3

Effects of the ECB's QE on loans and deposits.

\begin{tabular}{|c|c|c|c|c|c|c|}
\hline & \multicolumn{3}{|c|}{ Dependent variable: $L O A N T A_{i t}$} & \multicolumn{3}{|c|}{ Dependent variable: $D_{E P T A_{i t}}$} \\
\hline & $\begin{array}{l}\text { 1-month } \\
\text { Euribor }\end{array}$ & $\begin{array}{l}\text { 3-months } \\
\text { Euribor }\end{array}$ & EONIA & $\begin{array}{l}\text { 1-month } \\
\text { Euribor }\end{array}$ & $\begin{array}{c}\text { 3-months } \\
\text { Euribor }\end{array}$ & EONIA \\
\hline & (1) & (2) & (3) & (4) & (5) & (6) \\
\hline$\beta_{1}$ & $\begin{array}{l}-0.078^{*} \\
(0.042)\end{array}$ & $\begin{array}{l}-0.074 \\
(0.056)\end{array}$ & $\begin{array}{l}-0.093^{* *} \\
(0.042)\end{array}$ & $\begin{array}{l}-0.226^{* * * *} \\
(0.053)\end{array}$ & $\begin{array}{l}-0.273^{* * *} \\
(0.070)\end{array}$ & $\begin{array}{l}-0.249^{* * * *} \\
(0.053)\end{array}$ \\
\hline$\beta_{2}$ & $\begin{array}{c}0.011 \\
(0.035)\end{array}$ & $\begin{array}{l}-0.004 \\
(0.048)\end{array}$ & $\begin{array}{c}0.020 \\
(0.035)\end{array}$ & $\begin{array}{c}-0.160^{* * * *} \\
(0.047)\end{array}$ & $\begin{array}{c}-0.153^{* *} \\
(0.063)\end{array}$ & $\begin{array}{c}-0.184^{* * *} \\
(0.046)\end{array}$ \\
\hline$\beta_{3}$ & $\begin{array}{c}0.005 \\
(0.005)\end{array}$ & $\begin{array}{c}0.005 \\
(0.005)\end{array}$ & $\begin{array}{c}0.006 \\
(0.006)\end{array}$ & $\begin{array}{c}0.002 \\
(0.006)\end{array}$ & $\begin{array}{l}-0.001 \\
(0.006)\end{array}$ & $\begin{array}{c}0.005 \\
(0.008)\end{array}$ \\
\hline$\beta_{4}$ & $\begin{array}{c}0.002 \\
(0.004)\end{array}$ & $\begin{array}{c}0.002 \\
(0.004)\end{array}$ & $\begin{array}{c}0.001 \\
(0.005)\end{array}$ & $\begin{array}{c}-0.017^{* * *} \\
(0.005)\end{array}$ & $\begin{array}{c}-0.019^{* * * *} \\
(0.005)\end{array}$ & $\begin{array}{c}-0.023^{* * *} \\
(0.007)\end{array}$ \\
\hline$\beta_{5}$ & $\begin{array}{c}-0.013^{* * * *} \\
(0.002)\end{array}$ & $\begin{array}{c}-0.012^{* * * *} \\
(0.002)\end{array}$ & $\begin{array}{c}-0.015^{* * * *} \\
(0.003)\end{array}$ & $\begin{array}{l}0.014^{* * * *} \\
(0.003)\end{array}$ & $\begin{array}{c}0.012^{* * * *} \\
(0.003)\end{array}$ & $\begin{array}{c}0.015^{* * * *} \\
(0.003)\end{array}$ \\
\hline$\beta_{6}$ & $\begin{array}{c}-0.009^{* * * *} \\
(0.003)\end{array}$ & $\begin{array}{c}-0.008^{* * * *} \\
(0.003)\end{array}$ & $\begin{array}{c}-0.009^{* * * *} \\
(0.003)\end{array}$ & $\begin{array}{l}0.021^{* * * *} \\
(0.004)\end{array}$ & $\begin{array}{l}0.021^{* * *} \\
(0.004)\end{array}$ & $\begin{array}{l}0.023^{* * * *} \\
(0.004)\end{array}$ \\
\hline$X_{i, t-1}^{\prime}$ & Yes & Yes & Yes & Yes & Yes & Yes \\
\hline Country $\times$ Time & Yes & Yes & Yes & Yes & Yes & Yes \\
\hline $\mathrm{N}$ & 1,397 & 1,397 & 1,397 & 1,397 & 1,397 & 1,397 \\
\hline $\begin{array}{l}\text { Wald test } \\
\text { (p-value })\end{array}$ & 0.0000 & 0.0000 & 0.0000 & 0.0000 & 0.0000 & 0.0000 \\
\hline $\begin{array}{l}\text { Breusch Pagan test } \\
(p \text {-value })\end{array}$ & 0.0000 & 0.0000 & 0.0000 & 0.0000 & 0.0000 & 0.0000 \\
\hline $\begin{array}{l}\text { Hausman } \\
(p \text {-value })\end{array}$ & 0.0558 & 0.0493 & 0.0610 & 0.4142 & 0.9994 & 0.5295 \\
\hline $\begin{array}{l}\text { Wooldridge test } \\
\text { (p-value })\end{array}$ & 0.7897 & 0.7824 & 0.7778 & 0.3661 & 0.3748 & 0.3707 \\
\hline $\mathrm{H}_{0}: \beta_{1}=\beta_{2}$ & 0.0894 & 0.3240 & 0.0292 & 0.3199 & 0.1918 & 0.3243 \\
\hline $\mathrm{H}_{0}: \beta_{3}=\beta_{4}$ & 0.6170 & 0.6902 & 0.5654 & 0.0152 & 0.0116 & 0.0043 \\
\hline $\mathrm{H}_{0}: \beta_{5}=\beta_{6}$ & 0.1575 & 0.1930 & 0.1354 & 0.0000 & 0.0000 & 0.0000 \\
\hline $\mathrm{H}_{0}: \beta_{1}=\beta_{3}$ & 0.0525 & 0.1642 & 0.0246 & 0.0000 & 0.0001 & 0.0000 \\
\hline $\mathrm{H}_{0}: \beta_{1}=\beta_{5}$ & 0.1226 & 0.2673 & 0.0663 & 0.0000 & 0.0001 & 0.0000 \\
\hline $\mathrm{H}_{0}: \beta_{3}=\beta_{5}$ & 0.0000 & 0.0000 & 0.0003 & 0.0315 & 0.0081 & 0.1777 \\
\hline $\mathrm{H}_{0}: \beta_{2}=\beta_{4}$ & 0.8035 & 0.9015 & 0.6001 & 0.0027 & 0.0343 & 0.0007 \\
\hline $\mathrm{H}_{0}: \beta_{2}=\beta_{6}$ & 0.5854 & 0.9271 & 0.4036 & 0.0030 & 0.0360 & 0.0005 \\
\hline $\mathrm{H}_{0}: \beta_{4}=\beta_{6}$ & 0.0138 & 0.0060 & 0.0421 & 0.4744 & 0.6034 & 0.9645 \\
\hline
\end{tabular}

Note: This table shows the results when the macroeconomic interest rates are regressed against the loans to total assets ratio $\left(L_{O A N T A_{i t}}\right)$ and the deposits to total assets ratio $\left(D E P T A_{i t}\right)$, as dependent variables. Regressions are estimated using the Ordinary Least Square (OLS) estimator with fixed effects for the period 2002Q1 - 2016Q4. Heteroscedasticity is tested using the Breusch Pagan test under the null of no significant differences across units, i.e., no panel effects. The correlation of the individual term $\left(v_{i}\right)$ with the regressors is tested using the Hausman test under the null of no correlation, i.e., the randomeffects estimator is valid. Autocorrelation is tested using the Wooldridge test under the null of no serial correlation. All the regressions contain individual fixed effects, and the standard errors are clustered at the bank specialization level. *, **, ***, denote minimum $10 \%, 5 \%$ and $1 \%$ level of significance, respectively. 
Table 4

Effects of the ECB's QE on banking concentration for periphery versus core country banks.

\begin{tabular}{|c|c|c|c|c|c|c|c|c|c|}
\hline & \multicolumn{3}{|c|}{ Dependent variable: $H_{H I}^{C r_{i t}}$} & \multicolumn{3}{|c|}{ Dependent variable: $H H^{D e p}{ }_{i t}$} & \multicolumn{3}{|c|}{$\begin{array}{c}\text { Dependent variable: } \\
\operatorname{Ln}\left(\text { Banks }_{h t}\right)\end{array}$} \\
\hline & 1-month Euribor & $\begin{array}{l}\text { 3-months } \\
\text { Euribor }\end{array}$ & EONIA & $\begin{array}{l}\text { 1-month } \\
\text { Euribor }\end{array}$ & $\begin{array}{l}\text { 3-months } \\
\text { Euribor }\end{array}$ & EONIA & $\begin{array}{l}\text { 1-month } \\
\text { Euribor }\end{array}$ & $\begin{array}{l}\text { 3-months } \\
\text { Euribor }\end{array}$ & EONIA \\
\hline & (1) & $(2)$ & (3) & (4) & $(5)$ & (6) & $(7)$ & $(8)$ & (9) \\
\hline$\beta_{1}$ & $\begin{array}{l}0.608^{* * *} \\
(0.124)\end{array}$ & $\begin{array}{l}0.690^{* * *} \\
(0.164)\end{array}$ & $\begin{array}{c}0.624^{* * *} \\
(0.122)\end{array}$ & $\begin{array}{l}0.763^{* * *} \\
(0.122)\end{array}$ & $\begin{array}{c}0.875^{* * *} \\
(0.165)\end{array}$ & $\begin{array}{l}0.785^{* * *} \\
(0.119)\end{array}$ & $\begin{array}{l}0.768^{* * *} \\
(0.129)\end{array}$ & $\begin{array}{l}0.791^{* * * *} \\
(0.142)\end{array}$ & $\begin{array}{l}0.904^{* * *} \\
(0.149)\end{array}$ \\
\hline$\beta_{2}$ & $\begin{array}{l}0.402^{* * *} \\
(0.076)\end{array}$ & $\begin{array}{l}0.400^{* * *} \\
(0.092)\end{array}$ & $\begin{array}{c}0.433^{* * *} \\
(0.077)\end{array}$ & $\begin{array}{l}0.335^{* * *} \\
(0.077)\end{array}$ & $\begin{array}{c}0.282^{* * *} \\
(0.093)\end{array}$ & $\begin{array}{l}0.376^{* * *} \\
(0.078)\end{array}$ & $\begin{array}{l}0.530^{* * *} \\
(0.057)\end{array}$ & $\begin{array}{l}0.627^{* * *} \\
(0.067)\end{array}$ & $\begin{array}{l}0.577^{* * *} \\
(0.063)\end{array}$ \\
\hline$\beta_{3}$ & $\begin{array}{l}0.019^{*} \\
(0.010)\end{array}$ & $\begin{array}{l}0.017^{*} \\
(0.010)\end{array}$ & $\begin{array}{l}0.026^{* *} \\
(0.013)\end{array}$ & $\begin{array}{l}0.020^{* *} \\
(0.010)\end{array}$ & $\begin{array}{l}0.020^{* *} \\
(0.010)\end{array}$ & $\begin{array}{l}0.025^{*} \\
(0.013)\end{array}$ & $\begin{array}{l}0.070^{* * *} \\
(0.007)\end{array}$ & $\begin{array}{l}0.076^{* * *} \\
(0.008)\end{array}$ & $\begin{array}{l}0.080^{* * *} \\
(0.008)\end{array}$ \\
\hline$\beta_{4}$ & $\begin{array}{c}0.011 \\
(0.009)\end{array}$ & $\begin{array}{c}0.011 \\
(0.008)\end{array}$ & $\begin{array}{c}0.014 \\
(0.011)\end{array}$ & $\begin{array}{l}0.061^{* * *} \\
(0.009)\end{array}$ & $\begin{array}{l}0.057^{* * *} \\
(0.008)\end{array}$ & $\begin{array}{l}0.078^{* * *} \\
(0.012)\end{array}$ & $\begin{array}{c}0.000 \\
(0.003)\end{array}$ & $\begin{array}{c}0.001 \\
(0.003)\end{array}$ & $\begin{array}{c}0.000 \\
(0.004)\end{array}$ \\
\hline$\beta_{5}$ & $\begin{array}{c}0.044^{* * *} \\
(0.008)\end{array}$ & $\begin{array}{c}0.040^{* * *} \\
(0.008)\end{array}$ & $\begin{array}{c}0.050^{* * *} \\
(0.009)\end{array}$ & $\begin{array}{c}0.049^{* * * *} \\
(0.008)\end{array}$ & $\begin{array}{c}0.046^{* * *} \\
(0.007)\end{array}$ & $\begin{array}{c}0.054^{\text {**** }} \\
(0.008)\end{array}$ & $\begin{array}{l}0.039^{* *} \\
(0.016)\end{array}$ & $\begin{array}{c}0.042^{* * * *} \\
(0.015)\end{array}$ & $\begin{array}{l}0.039^{* *} \\
(0.017)\end{array}$ \\
\hline$\beta_{6}$ & $\begin{array}{l}0.024^{* *} \\
(0.010)\end{array}$ & $\begin{array}{l}0.023^{* *} \\
(0.009)\end{array}$ & $\begin{array}{l}0.023^{* *} \\
(0.011)\end{array}$ & $\begin{array}{l}-0.015 \\
(0.009) \\
\end{array}$ & $\begin{array}{c}-0.013 \\
(0.009) \\
\end{array}$ & $\begin{array}{c}-0.015 \\
(0.010) \\
\end{array}$ & $\begin{array}{c}0.017^{* * *} \\
(0.004) \\
\end{array}$ & $\begin{array}{c}0.015^{* * * *} \\
(0.004)\end{array}$ & $\begin{array}{c}0.019^{* * *} \\
(0.004)\end{array}$ \\
\hline$X_{i, t-1}^{\prime}$ & Yes & Yes & Yes & Yes & Yes & Yes & Yes & Yes & Yes \\
\hline $\begin{array}{l}\text { Country } \\
\times \text { Time }\end{array}$ & Yes & Yes & Yes & Yes & Yes & Yes & Yes & Yes & Yes \\
\hline$N$ & 1,397 & 1,397 & 1,397 & 1,397 & 1,397 & 1,397 & 1,397 & 1,397 & 1,397 \\
\hline $\begin{array}{l}\text { Wald } \\
\text { test }(p \text { - } \\
\text { value })\end{array}$ & 0.0000 & 0.0000 & 0.0000 & 0.0000 & 0.0000 & 0.0000 & 0.0000 & 0.0000 & 0.0000 \\
\hline $\begin{array}{l}\text { Breusch } \\
\text { Pagan test } \\
\text { (p-value) }\end{array}$ & 0.0000 & 0.0000 & 0.0000 & 0.0000 & 0.0000 & 0.0000 & 0.0000 & 0.0000 & 0.0000 \\
\hline $\begin{array}{l}\text { Hausman } \\
\text { test } \\
(p \text {-value })\end{array}$ & 0.0000 & 0.0000 & 0.0000 & 0.0001 & 0.0003 & 0.0000 & 0.0000 & 0.0000 & 0.0000 \\
\hline
\end{tabular}




\begin{tabular}{|c|c|c|c|c|c|c|c|c|c|}
\hline $\begin{array}{l}\text { Wooldridge } \\
\text { test } \\
(p \text {-value })\end{array}$ & 0.0055 & 0.0061 & 0.0061 & 0.0379 & 0.0427 & 0.0362 & 0.0000 & 0.0000 & 0.0000 \\
\hline $\mathrm{H}_{0}: \beta_{1}=\beta_{2}$ & 0.0615 & 0.0627 & 0.0687 & 0.0002 & 0.0002 & 0.0002 & 0.1207 & 0.3471 & 0.0581 \\
\hline $\mathrm{H}_{0}: \beta_{3}=\beta_{4}$ & 0.5602 & 0.6680 & 0.5124 & 0.0032 & 0.0053 & 0.0034 & 0.0000 & 0.0000 & 0.0000 \\
\hline $\mathrm{H}_{0}: \beta_{5}=\beta_{6}$ & 0.0000 & 0.0000 & 0.0000 & 0.0000 & 0.0000 & 0.0000 & 0.1996 & 0.1040 & 0.2648 \\
\hline $\mathrm{H}_{0}: \beta_{1}=\beta_{3}$ & 0.0000 & 0.0001 & 0.0000 & 0.0000 & 0.0000 & 0.0000 & 0.0000 & 0.0000 & 0.0000 \\
\hline $\mathrm{H}_{0}: \beta_{1}=\beta_{5}$ & 0.0000 & 0.0001 & 0.0000 & 0.0000 & 0.0000 & 0.0000 & 0.0000 & 0.0000 & 0.0000 \\
\hline $\mathrm{H}_{0}: \beta_{3}=\beta_{5}$ & 0.0004 & 0.0006 & 0.0129 & 0.0000 & 0.0001 & 0.0018 & 0.0697 & 0.0393 & 0.0256 \\
\hline $\mathrm{H}_{0}: \beta_{2}=\beta_{4}$ & 0.0000 & 0.0000 & 0.0000 & 0.0006 & 0.0178 & 0.0002 & 0.0000 & 0.0000 & 0.0000 \\
\hline $\mathrm{H}_{0}: \beta_{2}=\beta_{6}$ & 0.0000 & 0.0000 & 0.0000 & 0.0000 & 0.0012 & 0.0000 & 0.0000 & 0.0000 & 0.0000 \\
\hline $\mathrm{H}_{0}: \beta_{4}=\beta_{6}$ & 0.0050 & 0.0026 & 0.0083 & 0.0000 & 0.0000 & 0.0000 & 0.0000 & 0.0000 & 0.0000 \\
\hline
\end{tabular}

Note: This table shows the results when the macroeconomic interest rates are regressed against the concentration indicators for loans $\left(H H I^{C r}{ }_{i t}\right)$, deposits $\left(H H I^{\text {Dep }}{ }_{i t}\right)$

and the number of banks ( $\operatorname{Ln}\left(\right.$ Banks $\left.\left._{h t}\right)\right)$, as dependent variables. Regressions are estimated using the random effects estimator for the period $2002 \mathrm{Q} 1-2016 \mathrm{Q} 4$.

Heteroscedasticity is tested using the Breusch Pagan test under the null of no significant differences across units, i.e., no panel effects. The correlation of the

individual term $\left(v_{i}\right)$ with the regressors is tested using the Hausman test under the null of no correlation, i.e., the random-effects estimator is valid. Autocorrelation is tested using the Wooldridge test under the null of no serial correlation. All the regressions contain individual fixed effects, and the standard errors are clustered at the bank specialization level. *,**, ***, denote minimum $10 \%, 5 \%$ and $1 \%$ level of significance, respectively. 
Table 5

The transmission channel for periphery versus core country banks. Instrumental variables estimator.

\begin{tabular}{|c|c|c|c|c|c|c|c|c|c|c|c|c|}
\hline & \multicolumn{6}{|c|}{ Dependent variable: $L O A N T A_{i t}$} & \multicolumn{6}{|c|}{ Dependent variable: $D E P T A_{i t}$} \\
\hline & \multicolumn{2}{|c|}{ 1-month Euribor } & \multicolumn{2}{|c|}{ 3-month Euribor } & \multicolumn{2}{|c|}{ EONIA } & \multicolumn{2}{|c|}{ 1-month Euribor } & \multicolumn{2}{|c|}{ 3-month Euribor } & \multicolumn{2}{|c|}{ EONIA } \\
\hline & Core & Periphery & Core & Periphery & Core & Periphery & Core & Periphery & Core & Periphery & Core & Periphery \\
\hline & (1) & (2) & (3) & (4) & $(5)$ & (6) & (7) & $(8)$ & (9) & $(10)$ & (11) & $(12)$ \\
\hline \multirow[t]{2}{*}{$\operatorname{Ln}\left(\right.$ Banks $\left._{h, t-1}\right)$} & $\begin{array}{c}0.012 \\
(0.032)\end{array}$ & $\begin{array}{l}0.134^{*} \\
(0.081)\end{array}$ & $\begin{array}{c}0.014 \\
(0.030)\end{array}$ & $\begin{array}{l}0.142^{*} \\
(0.084)\end{array}$ & $\begin{array}{c}0.005 \\
(0.032)\end{array}$ & $\begin{array}{l}0.139^{*} \\
(0.084)\end{array}$ & $\begin{array}{c}0.089 \\
(0.086)\end{array}$ & $\begin{array}{l}0.756^{* * *} \\
(0.210)\end{array}$ & $\begin{array}{c}0.091 \\
(0.080)\end{array}$ & $\begin{array}{l}0.789^{\text {**** }} \\
(0.217)\end{array}$ & $\begin{array}{c}0.066 \\
(0.087)\end{array}$ & $\begin{array}{l}0.760^{* * * *} \\
(0.220)\end{array}$ \\
\hline & \multicolumn{12}{|c|}{ First stage } \\
\hline$M P_{t-1}$ & $\begin{array}{c}0.032^{\text {*** }} \\
(0.008)\end{array}$ & $\begin{array}{l}0.051^{\text {*** }} \\
(0.011)\end{array}$ & $\begin{array}{c}0.030^{* * *} \\
(0.008)\end{array}$ & $\begin{array}{l}0.053^{\text {**** }} \\
(0.011)\end{array}$ & $\begin{array}{c}0.033^{* * *} \\
(0.009)\end{array}$ & $\begin{array}{l}0.053^{* * * *} \\
(0.012)\end{array}$ & $\begin{array}{l}0.034^{* * *} \\
(0.008)\end{array}$ & $\begin{array}{l}0.053^{* * *} \\
(0.011)\end{array}$ & $\begin{array}{l}0.033^{* * *} \\
(0.007)\end{array}$ & $\begin{array}{l}0.054^{* * *} \\
(0.011)\end{array}$ & $\begin{array}{c}0.035^{\text {*** }} \\
(0.008)\end{array}$ & $\begin{array}{l}0.053^{* * *} \\
(0.012)\end{array}$ \\
\hline$H H I^{C r}{ }_{h, t-1}$ & $\begin{array}{l}-0.052 \\
(0.037)\end{array}$ & $\begin{array}{c}-0.123 \\
(.085)\end{array}$ & $\begin{array}{l}-0.052 \\
(0.037)\end{array}$ & $\begin{array}{l}-0.121 \\
(0.085)\end{array}$ & $\begin{array}{l}-0.053 \\
(0.037)\end{array}$ & $\begin{array}{l}-0.132 \\
(0.085)\end{array}$ & & & & & & \\
\hline$H H I_{h, t-1}^{D e p}$ & & & & & & & $\begin{array}{c}0.020 \\
(0.033)\end{array}$ & $\begin{array}{c}0.055 \\
(0.085)\end{array}$ & $\begin{array}{c}0.020 \\
(0.033)\end{array}$ & $\begin{array}{c}0.060 \\
(0.084)\end{array}$ & $\begin{array}{c}0.019 \\
(0.033)\end{array}$ & $\begin{array}{c}0.046 \\
(0.085)\end{array}$ \\
\hline$X_{i, t-1}^{\prime}$ & Yes & Yes & Yes & Yes & Yes & Yes & Yes & Yes & Yes & Yes & Yes & Yes \\
\hline Country $\times$ Time & Yes & Yes & Yes & Yes & Yes & Yes & Yes & Yes & Yes & Yes & Yes & Yes \\
\hline$N$ & 1,397 & 1,397 & 1,397 & 1,397 & 1,397 & 1,397 & 1,397 & 1,397 & 1,397 & 1,397 & 1,397 & 1,397 \\
\hline $\begin{array}{l}\text { Sargan test } \\
(p \text {-value })\end{array}$ & 0.2566 & 0.7282 & 0.2699 & 0.7144 & 0.2635 & 0.7775 & 0.8336 & 0.4700 & 0.8700 & 0.4699 & 0.8375 & 0.4748 \\
\hline $\begin{array}{l}\text { Wald test } \\
(p \text {-value })\end{array}$ & 0.0000 & 0.0000 & 0.0000 & 0.0000 & 0.0000 & 0.0000 & 0.0000 & 0.0000 & 0.0000 & 0.0000 & 0.0000 & 0.0000 \\
\hline
\end{tabular}

Note: This table shows the results when the natural logarithm of the number of banks at the country level (Ln (Banksht)) is regressed against the loans to total assets ratio $\left(L O A N T A_{i t}\right)$ and the deposits to total assets ratio $\left(D E P T A_{i t}\right)$, as dependent variables. Regressions are estimated using the instrumental variables (IV) estimator with fixed effects for the period 2002Q1 - 2016Q4. Heteroscedasticity is tested using the Breusch Pagan test under the null of no significant differences across units, i.e., no panel effects. The selected instruments are the macroeconomic interest rates $\left(M P_{t-1}\right)(1$-month Euribor, 3-month Euribor and EONIA) and the concentration indices for credit $\left(\mathrm{HHI}^{\mathrm{Cr}}{ }_{h, t-1}\right)$ and deposits $\left(\mathrm{HHI}_{h, t-1}^{\mathrm{Dep}}\right)$ markets lagged by one quarter for country $h$. Instruments validated by the Sargan test, under the null of exogeneity, checking the lack of correlation between the instruments and the error term of the main equation. All the regressions contain individual and time fixed effects, and the standard errors are clustered at the bank specialization level. *, **, ***, denote minimum $10 \%, 5 \%$ and $1 \%$ level of significance, respectively. 
Table 6

Effects of banking competition on financial stability

\begin{tabular}{|c|c|c|}
\hline & $\begin{array}{c}\text { Dependent variable: } \\
\operatorname{Ln}\left(Z_{i t}\right)\end{array}$ & $\begin{array}{c}\text { Dependent variable: } \\
N P L_{i t}\end{array}$ \\
\hline & (1) & (2) \\
\hline \multirow[t]{2}{*}{$\beta^{\prime}{ }_{1}$} & $-0.322^{*}$ & $0.058^{* * *}$ \\
\hline & $(0.171)$ & $(0.007)$ \\
\hline \multirow{2}{*}{$\beta_{2}{ }_{2}$} & -0.095 & -0.011 \\
\hline & $(0.134)$ & $(0.008)$ \\
\hline \multirow[t]{2}{*}{$\beta_{3}^{\prime}$} & -0.170 & $0.065^{* * * *}$ \\
\hline & $(0.167)$ & $(0.007)$ \\
\hline \multirow[t]{2}{*}{$\beta^{\prime}{ }_{4}$} & 0.151 & -0.002 \\
\hline & $(0.139)$ & $(0.008)$ \\
\hline \multirow[t]{2}{*}{$\beta^{\prime}{ }_{5}$} & -0.954 & $0.197^{* * *}$ \\
\hline & $(0.785)$ & $(0.046)$ \\
\hline \multirow[t]{2}{*}{$\beta^{\prime}{ }_{6}$} & $2.855^{* *}$ & $0.100^{* *}$ \\
\hline & $(1.275)$ & $(0.047)$ \\
\hline$X_{i, t-1}^{\prime}$ & Yes & Yes \\
\hline Country $\times$ Time & Yes & Yes \\
\hline$N$ & 1,397 & 1,397 \\
\hline Wald test $(p$-value $)$ & 0.0000 & 0.0000 \\
\hline $\begin{array}{l}\text { Breusch Pagan test } \\
(p \text {-value })\end{array}$ & 0.0000 & 0.0000 \\
\hline $\begin{array}{l}\text { Hausman test } \\
\text { (p-value })\end{array}$ & 0.2344 & 0.0000 \\
\hline $\begin{array}{l}\text { Wooldridge test } \\
(p \text {-value })\end{array}$ & 0.0004 & 0.0068 \\
\hline $\mathrm{H}_{0}: \beta^{\prime}{ }_{1}=\beta^{\prime}{ }_{2}$ & 0.1254 & 0.0000 \\
\hline $\mathrm{H}_{0}: \beta^{\prime}{ }_{3}=\beta^{\prime}{ }_{4}$ & 0.0278 & 0.0000 \\
\hline $\mathrm{H}_{0}: \beta^{\prime}{ }_{5}=\beta^{\prime}{ }_{6}$ & 0.0083 & 0.0000 \\
\hline
\end{tabular}




\begin{tabular}{|c|c|c|}
\hline $\mathrm{H}_{0}: \beta_{1}^{\prime}=\beta^{\prime}{ }_{3}$ & 0.1805 & 0.0793 \\
\hline $\mathrm{H}_{0}: \beta^{\prime}{ }_{1}=\beta^{\prime}{ }_{5}$ & 0.4193 & 0.0023 \\
\hline $\mathrm{H}_{0}: \beta^{\prime}{ }_{3}=\beta^{\prime}{ }_{5}$ & 0.3120 & 0.0032 \\
\hline $\mathrm{H}_{0}: \beta^{\prime}{ }_{2}=\beta^{\prime}{ }_{4}$ & 0.0040 & 0.0436 \\
\hline $\mathrm{H}_{0}: \beta^{\prime}{ }_{2}=\beta^{\prime}{ }_{6}$ & 0.0183 & 0.0484 \\
\hline $\mathrm{H}_{0}: \beta^{\prime}{ }_{4}=\beta_{6}^{\prime}$ & 0.0292 & 0.0273 \\
\hline
\end{tabular}

Note: This table shows the results when the risk-free adjusted Lerner index ( Lerner $\left._{i t}\right)$ is regressed against the inverse probability of bank default $\left(\operatorname{Ln}\left(Z_{i t}\right)\right)$ and the NPL ratio $\left(N P L_{i t}\right)$, as dependent variables. Regressions are estimated using the Ordinary Least Square (OLS) estimator with fixed effects for the period 2002Q1 - 2016Q4. Heteroscedasticity is tested through the Breusch Pagan test under the null of no significant differences across units, i.e., no panel effects. The correlation of the individual term $\left(v_{i}\right)$ with the regressors is tested using the Hausman test under the null of no correlation, i.e., the random-effects estimator is valid. Autocorrelation is tested using the Wooldridge test under the null of no serial correlation. All the regressions contain individual fixed effects, and the standard errors are clustered at the bank specialization level. *, **, ***, denote minimum $10 \%, 5 \%$ and $1 \%$ level of significance, respectively. 
Table 7

Effects of reductions in the number of banks on financial stability. Instrumental variables estimator.

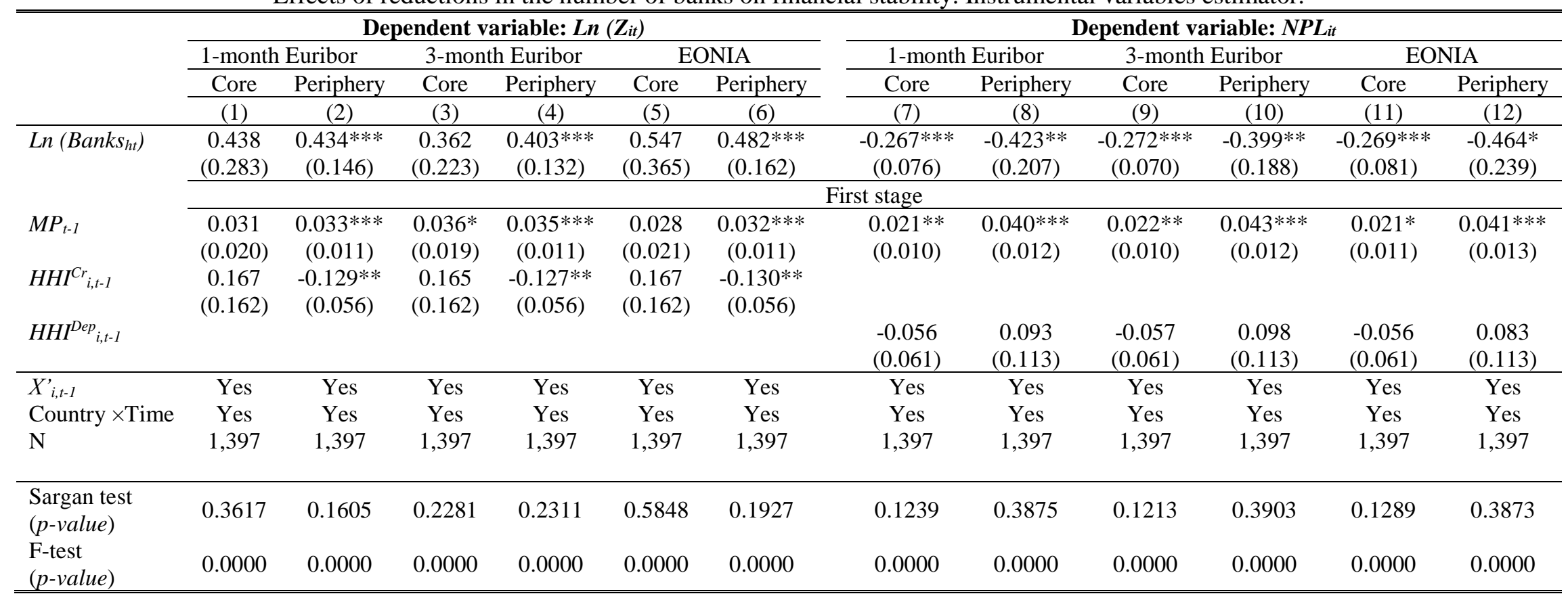

Note: This table shows the results when the natural logarithm of the number of banks at the country level ( $\operatorname{Ln}($ Banksht)) is regressed against the natural logarithm of the Zscore $\left(\operatorname{Ln}\left(Z_{i t}\right)\right)$ and the NPLs ratio $\left(N P L_{i t}\right)$ as dependent variables. Regressions are estimated using the instrumental variables (IV) estimator with fixed effects for the period 2002Q1 - 2016Q4. Heteroscedasticity is tested through the Breusch Pagan test under the null of no significant differences across units, i.e., no panel effects. The selected instruments are the macroeconomic interest rates $\left(M P_{t-1}\right)$ (1-month Euribor, 3-month Euribor and EONIA) and the concentration indices for credit $\left(H H I^{C r} r_{t-1}\right)$ and deposits $\left(H_{H} I^{D e p}{ }_{h, t-1}\right)$ markets lagged by one quarter for country $h$. Instruments validated by the Sargan test, under the null of exogeneity, checking the lack of correlation between the instruments and the error term of the main equation. All the regressions contain individual and time fixed effects, and the standard errors are clustered at the bank specialization level. *,**,***, denote minimum $10 \%, 5 \%$ and $1 \%$ level of significance, respectively. 
